Materials Needs and Opportunities in the Pulp and Paper Industry

\author{
Advanced Industrial Materials \\ (AIM) Program
}

August 1995

Office of Industrial Technologies

U.S. Department of Energy 
This report has been reproduced directly from the best available copy.

Available to DOE and DOE contractors from the Office of Scientific and Technical Information, P.O. Box 62, Oak Ridge, TN 37831; prices available from (615) 576-8401, FTS 626-8401.

Available to the public from the National Technical Information Service, U.S. Department of Commerce, 5285 Port Royal Rd., Springfield, VA 22161.

This report was prepared as an account of work sponsored by an agency of the United States Government. Neither the United States Government nor any agency thereof, nor any of their employees, makes any warranty, express or implied, or assumes any legal liability or responsibility for the accuracy, completeness, or usefulness of any information, apparatus, product, or process disclosed, or represents that its use would not infringe privately owned rights. Reference herein to any specific commercial product, process, or service by trade name, trademark, manufacturer, or otherwise, does not necessarily constitute or imply its endorsement, recommendation, or favoring by the United States Government or any agency thereof. The views and opinions of authors expressed herein do not necessarily state or reflect those of the United States Government or any agency thereof. 
MATERIALS NEEDS AND OPPORTUNITIES

IN THE PULP AND PAPER INDUSTRY

Date Published: August 1995

NOTICE: This document contains information of a preliminary nature. It is subject to revision or correction and therefore does not represent a final report.

Prepared for the U.S. Department of Energy Office of Industrial Technologies Advanced Industrial Materials (AIM) Program ED 2204000

P. Angelini, Compiler

Prepared by the OAK RIDGE NATIONAL LABORATORY

Oak Ridge, Tennessee 37831-6065 managed by MARTIN MARIETTA ENERGY SYSTEMS, INC. for the U.S. DEPARTMENT OF ENERGY under contract DE-AC05-84OR21400 

PREFACE (C. A. Sorrell and S. F. Sobczynski) $\ldots \ldots \ldots \ldots \ldots \ldots \ldots \ldots, 1$

1. WOOD PREPARATION $\ldots \ldots \ldots \ldots \ldots \ldots \ldots \ldots \ldots \ldots \ldots \ldots \ldots \ldots$

1.1 WOOD YARD OPERATIONS $\ldots \ldots \ldots \ldots \ldots \ldots \ldots \ldots \ldots \ldots, 3$

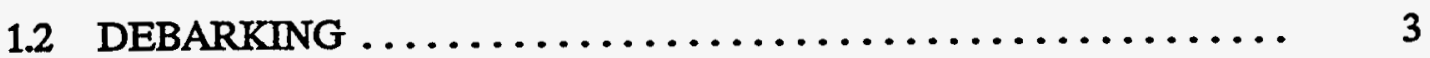

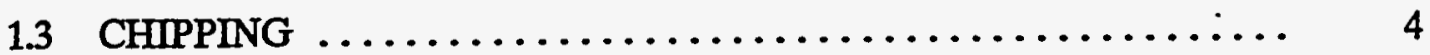

1.4 MATERIALS REQUIREMENTS ................... 4

2. PULP PREPARATION $\ldots \ldots \ldots \ldots \ldots \ldots \ldots \ldots \ldots \ldots \ldots \ldots \ldots \ldots \ldots \ldots$

2.1 MECHANICAL PULPING ...................... 5

2.1.1 Groundwood $\ldots \ldots \ldots \ldots \ldots \ldots \ldots \ldots \ldots \ldots \ldots \ldots \ldots \ldots$

2.1.2 Mechanical Refining $\ldots \ldots \ldots \ldots \ldots \ldots \ldots \ldots \ldots \ldots \ldots \ldots$

2.2 CHEMICAL PULPING $\ldots \ldots \ldots \ldots \ldots \ldots \ldots \ldots \ldots \ldots \ldots \ldots \ldots \ldots \ldots$

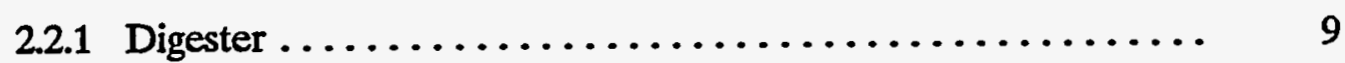

2.2.2 Recovery Boiler $\ldots \ldots \ldots \ldots \ldots \ldots \ldots \ldots \ldots \ldots \ldots, 9$

2.2.3 Chemical Recovery System .................. 11

2.2.4 New Processes ........................ 11

2.3 RECYCLED PAPER SYSTEMS $\ldots \ldots \ldots \ldots \ldots \ldots \ldots \ldots \ldots \ldots \ldots$

2.4 MATERIALS REQUIREMENTS $\ldots \ldots \ldots \ldots \ldots \ldots \ldots \ldots \ldots, 13$

3. BLEACHING $\ldots \ldots \ldots \ldots \ldots \ldots \ldots \ldots \ldots \ldots \ldots \ldots \ldots \ldots \ldots \ldots \ldots \ldots \ldots \ldots \ldots \ldots$

3.1 CURRENT BLEACHING METHODS ................ 15

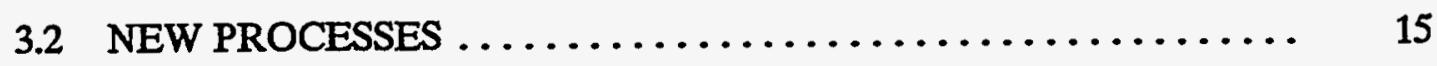

3.3 MATERIALS REQUIREMENTS $\ldots \ldots \ldots \ldots \ldots \ldots \ldots \ldots \ldots . \quad 16$

4. PAPERMAKING $\ldots \ldots \ldots \ldots \ldots \ldots \ldots \ldots \ldots \ldots \ldots \ldots \ldots \ldots \ldots \ldots \ldots \ldots \ldots \ldots$

4.1 STOCK PIPING AND HEADBOX ................ 17 
4.2 INTERMEDIATE STRUCTURES/DRYERS $\ldots \ldots \ldots \ldots \ldots \ldots \ldots, 18$

4.3 PAPER FINISHING AND HANDLING $\ldots \ldots \ldots \ldots \ldots \ldots . . \ldots$

4.4 NEW PROCESSES/GENERAL ISSUES $\ldots \ldots \ldots \ldots \ldots \ldots \ldots$.

4.5 MATERIALS REQUIREMENTS .................. 20

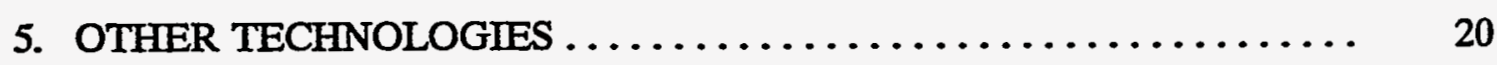

5.1 MOTORS/GENERATORS/TURBINES .............. 20

5.2 SENSORS AND CONTROLS $\ldots \ldots \ldots \ldots \ldots \ldots \ldots \ldots \ldots \ldots \ldots \ldots \ldots$

5.3 MATERIALS REQUIREMENTS .................. 22

6. ENVIRONMENTAL ASPECTS/WASTE HANDLING AND

MINIMIZATION $\ldots \ldots \ldots \ldots \ldots \ldots \ldots \ldots \ldots \ldots \ldots \ldots \ldots \ldots \ldots \ldots \ldots, 22$

6.1 MATERIALS REQUIREMENTS ................. 23

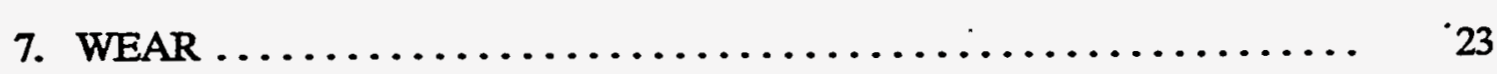

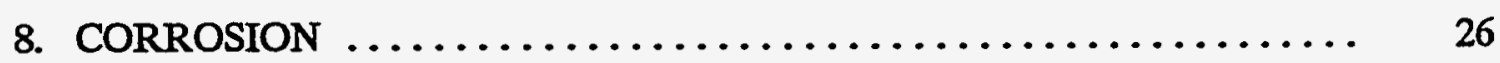

9. STRUCTURAL AND OTHER ASPECTS $\ldots \ldots \ldots \ldots \ldots \ldots \ldots \ldots . \ldots \ldots$

10. ACKNOWLEDGMENTS $\ldots \ldots \ldots \ldots \ldots \ldots \ldots \ldots \ldots \ldots \ldots \ldots \ldots \ldots \ldots \ldots$

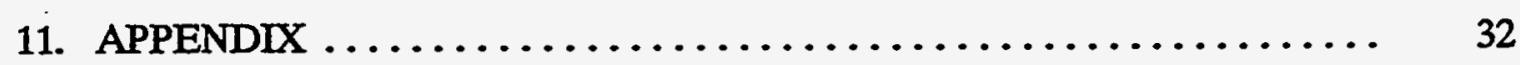




\section{PREFACE}

\section{ADVANCED INDUSTRIAL MATERIAIS (AIM) PROGRAM (C. A. Sorrell)}

The Department of Energy's (DOE) Office of Industrial Technologies (OIT) supports research and development (R\&D) in industry, the DOE national laboratories, and in universities to develop energy efficient, environmentally-acceptable industrial technologies. The Office of Industrial Technologies is working with seven energy-intensive industries to develop R\&D roadmaps that will facilitate cooperative government-industry efforts to achieve energy-efficient, environmentally-acceptable, sustainable industries of the future. The forest products industry is one of the industries with which OIT is working to develop an R\&D roadmap.

The Advanced Industrial Materials (AIM) Program of the Office of Industrial Technologies sponsors long-term, directed research on materials that will enable industry to develop and utilize more energy-efficient, sustainable processes and technologies. The purpose of the study described in this report was to identify the material R\&D needs and opportunities for the pulp and paper mill of the future.

\section{PULP AND PAPER MILL OF THE FUTURE (S. F. Sobczynski)}

During the past 12 years, DOE has, together with industry support, provided funding for the development of technologies that could have a significant impact on the energy efficiency, productivity, and environmental compliance of paper and paperboard manufacture. The paper industry has played an important role in the guidance of this $R \& D$ program.

An exciting new task is being undertaken to develop a more comprehensive and formalized strategic plan for DOE's paper program. This new plan, entitled Pulp and Paper Mill of the Future, will address the paper mill of the future.

The program will impact all National Energy Strategy (NES) goals. These include:

1. Economic Growth

- enhance U.S. position in global markets

- maintain U.S. competitiveness

2. Energy Security

- encourage the use of renewable energy resources

- promote energy self-sufficiency

3. Environmental Improvement

- promote environmentally acceptable processes

- maximize the utilization of resources

The program is also consistent with the mission of DOE, Energy Efficiency and Renewable Energy, and Office of Industrial Technologies (OIT). The mission of OIT is to facilitate research, development, and demonstration of energy-efficient, waste-reducing industrial technologies which are ultimately factors of successful global productivity and competitiveness. 
The program plan will be responsive to industry needs. The capital intensiveness of processes will be reduced. One goal is to have the enhanced technologies be more cost effective and less capital intensive. The objective will be to improve productivity and to reduce energy consumption. The environmental impact of current and future processing methods will also be minimized. The goal is to develop improved processing methods which will reduce effluents, air emission, and/or solid waste. The program will be structured to maximize the impact by leveraging industrial and federal budgets. In general, the industry is evolutionary, not revolutionary, and has low $R \& D$ budgets which are generally $\sim 1 \%$ of sales. DOE will leverage its funding with that from industrial and other federal programs and will seek joint ventures with sustained efforts to introduce new technologies.

Critical technologies will be evaluated that will address the near-, mid-, and long-term needs of the paper industry and those that would best benefit from federal sponsorship. The technology needs that are identified should span the spectrum from fundamental, or basic research knowledge, to applied R\&D activities encompassing pilot plants or commercial demonstrations. The program plan will have a time-phased approach: (1) in the near term (to year 2000), where appropriate, demonstrate particularly attractive technologies that are currently available but underutilized; (2) in the mid term (to year 2010), refine existing laboratory-scale concepts and develop these technologies with pilot-scale demonstrations; and (3) for the long term (to year 2020), develop completely improved new processes and materials and focus on areas with very substantial energy savings potential.

The major focus of the program will be on four general process areas. These include (1) chemical pulping and recovery, (2) mechanical pulping, (3) papermaking, and (4) advanced processes and systems that reduce environmental impact.

\section{THE MISSION STATEMENT FOR THE DOE PULP AND PAPER MILL OF THE FUTURE}

The mission of the DOE program is to enable the paper industry to increase production, reduce energy consumption, reduce operating costs, and meet environmental goals by 2020 . The program will identify and then fund $R \& D$ to develop, improve, and demonstrate retrofit and advanced technologies and, if the demonstrated economics and market needs then warrant, to facilitate the commercial utilization of these advances in the pulp, paper, and paperboard industry in the United States. The U.S. paper industry, universities, and national laboratories who conduct paper $R \& D$ have collectively and convincingly shown that there is a significant opportunity for advances in pulp, paper, and paperboard production processes of the future that will: conserve large amounts of energy, maintain low overall costs, increase resource utilization, decrease environmental impacts of these technologies, and lower safety or health risks to the public compared to those of currently practiced technologies.

DOE's role is to stimulate and nurture the research, development, demonstration, and communication of technology advances by the pulp and paper sector and to help industry realize the full potential of these technology advances, with as little investment and cost to the Government as required to take advantage of the great promise of these new technology advances for serving the public interest in the optimization of the use of our resources. 


\title{
MATERIAIS NEEDS AND OPPORTUNITIES IN THE PULP AND PAPER INDUSTRY ${ }^{*}$
}

\author{
P. Angelini, Compiler
}

\section{WOOD PREPARATION}

An important initial step in paper manufacture is the collection and processing of large logs into a form which can be subsequently handled and made into pulp. Major steps in wood preparation include wood yard operations, debarking, and chipping. Problems in the wood yard may affect the entire pulp and papermaking process.

\subsection{WOOD YARD OPERATTONS}

Logs are customarily delivered to the wood yard via trucks, trains, barges, or river flotation. These usually have been de-limbed and cut to the correct size for further processing. Operations in the wood yard involve miscellaneous grapplers for holding and moving these logs. If the logs are not cut to the proper size, high-speed saws or knives are used to cut them.

\section{$\underline{\text { Issues }}$}

Materials issues in the wood yard are generally not related to corrosion or elevated temperatures but to wear caused by erosion and abrasion. Bark contains significant quantities of soil and sand and sometimes water or saltwater, as well as contaminants such as nails, fence wire, etc. Transport chutes, belts, saws, and knives can suffer excessive wear from contamination introduced with the raw materials and also from certain types of hard wood.

Although materials used presently are almost always metallic, many ceramic materials possess the requisite strength and hardness to provide greater wear resistance. These include aluminum dioxide, zirconia-toughened alumina (ZTA), silicon nitride, silicon carbide, titanium diboride, and zirconia, along with traditional "hard metals" like cobalt-bonded tungsten carbide. Considerations for potential application are cost effectiveness (e.g., whether the reduced wear rate and lower consequent downtime for parts replacement justify the higher costs of ceramics); the ability to manufacture the requisite sizes; and durability during handling (material toughness).

\subsection{DEBARKING}

Debarking of the logs is required since the outer bark of trees usually does not contain fibrous materials and, consequently, is a contaminant in pulp and paper processes. Debarkers generally are open-ended cylinders through which the logs are rotated, rubbing against themselves and/or

\footnotetext{
${ }^{*}$ Research sponsored by the U.S. Department of Energy, Assistant Secretary for Energy Efficiency and Renewable Energy, Office of Industrial Technologies, Advanced Industrial Materials (AIM) Program, under contract DE-AC05-84OR21400 with Martin Marietta Energy Systems, Inc.
} 
the wall of the cylinder. The bark removed by the rubbing action drops through slots in the cylinder wall and can be burned for energy recovery.

\section{$\underline{\text { Issues }}$}

Abrasion by hard particulates, such as silicates retained as sand or dirt in the tree bark, causes wear of the debarking equipment.

\subsection{CHIPPING}

The debarked logs require further size reduction for processing. The operation for size reduction is called chipping and utilizes a large disk rotating on a horizontal axis or, alternatively, may use a drum configuration. The face of the disk, or the wall of the drum, is fitted with cutting knives that slice across the log, forming chips that pass through slots in the disk (or drum wall). The chipped wood is screened to remove large knots and oversized chips, which are separately reduced in size by mechanical means, and to remove fines, which are burned or pulped separately.

\section{Issues}

The saw blades in the slasher deck are subject to high impacts. The life of the cutting blades on the chipper is reduced if hardwoods are used. If the chipper and slasher are inoperative, chips from the storage yard are substituted. This may result in the introduction of rocks into subsequent processing steps with detrimental effects.

\subsection{MATERIAIS REQUIREMENTS}

- Metals, ceramics, and/or surface treatments or coatings with improved abrasion and impact resistance

- Improved materials and/or surface treatments to provide greater impact-resistant edges for chipper blades, saws, knives, and slasher deck blades

- Materials and/or surface treatments for improved abrasion resistance for log transport, chutes, debarkers, and recycle paper handling

\section{PULP PREPARATION}

The objective of the pulping process is to separate the cellulose fibers from the other components of the wood. Both chemical and mechanical pulping processes are used. Each pulping process is designed to yield a specific set of feedstock characteristics, which are set by the product being manufactured (newsprint, tissue, pasteboard, etc.).

Grinder mechanical pulping involves grinding of wet logs against an abrasive grindstone, often at temperatures of $100^{\circ} \mathrm{C}\left(212^{\circ} \mathrm{F}\right)$ or slightly higher, to mechanically separate the fibers. Refiner mechanical pulping incorporates the wood chips from the chipping operation into the interface 
between two counter-rotating surfaces which contain a series of corrugations that mechanically degrade the chip and expose the cellulose fibers. Thermomechanical pulping (TMP) involves presteaming or a mild chemical pretreatment of the wood chips to make them soft prior to fiber separation. Although TMP requires somewhat more energy, less fiber destruction occurs and higher quality pulp results. Chemical pulping generally involves digestion of the wood chips in solutions of sodium sulfide/sodium hydroxide (the Kraft process). This may involve elevated temperatures [up to $170^{\circ} \mathrm{C}\left(340^{\circ} \mathrm{F}\right)$ ] and pressures [up to $1 \mathrm{MPa}(150 \mathrm{psi})$ ]. After digestion, the pulp slurry is rapidly released from the pressure vessel through a vent onto a blow plate, with depressurization occurring instantaneously. Several other chemical pulping processes are used, such as the "sulfite" process, almost all of which utilize some sulfur-containing chemicals.

The materials issues depend on the type of pulping. Mechanical, or refiner pulping, causes wear from abrasion/erosion on the components, whereas chemical pulping results in exposure of containment materials to corrosive and erosive wear from the solutions/slurries.

The materials presently in common use are metals, except for the abrasive wheel in grinder mechanical pulping. Some fiber-reinforced plastics and other organic-based materials are utilized for vessel or pipe, pump, and valve linings.

\section{MECHANICAL PULPING}

In mechanical pulping, wood fibers are separated from each other by rolling, rubbing, or teasing, either against themselves or against a harder, specially designed surface. Chemical additions or the application of heat and pressure can be used to increase the quality of the pulp; however, the predominant pulping forces are mechanical. Mechanical pulping can be divided into two main areas: groundwood and disk refining.

\subsubsection{Groundwood}

Until recently, groundwood was the predominant means of mechanical pulping. The most common version is stone groundwood, in which pulp is formed by pressing debarked logs against a rotating grindstone, as shown in Fig. 1(a) [from Metals Handbook]. Water sprays are directed onto the stone, or ceramics, to prevent the fibers from burning, and the pulp is removed in the form of a slurry. Other variations include pressurized groundwood, in which pulping occurs at elevated temperature, and chemi-groundwood, in which a chemical pretreatment is used.

\section{Issues}

Wear resistance is the major materials concern in the groundwood process. Synthesized ceramic elements for grinding surfaces may be superior to stone grinding surfaces in some applications.

\subsubsection{Mechanical Refining}

Pulping by mechanical action in a rotating-disk attrition mill, called a refiner, as shown in Fig. 1(b) [from Metals Handbook], is widespread in the industry. Presteaming, with and without additional chemical treatment, may be used to enhance the fibrillization process. The refiner utilizes the action of two closely spaced disks as one rotates with respect to the other, or as they both rotate in opposite directions. Wood chips are fed into the gap between the disks at the 
ORNL-DWG 93M-5103

(a)
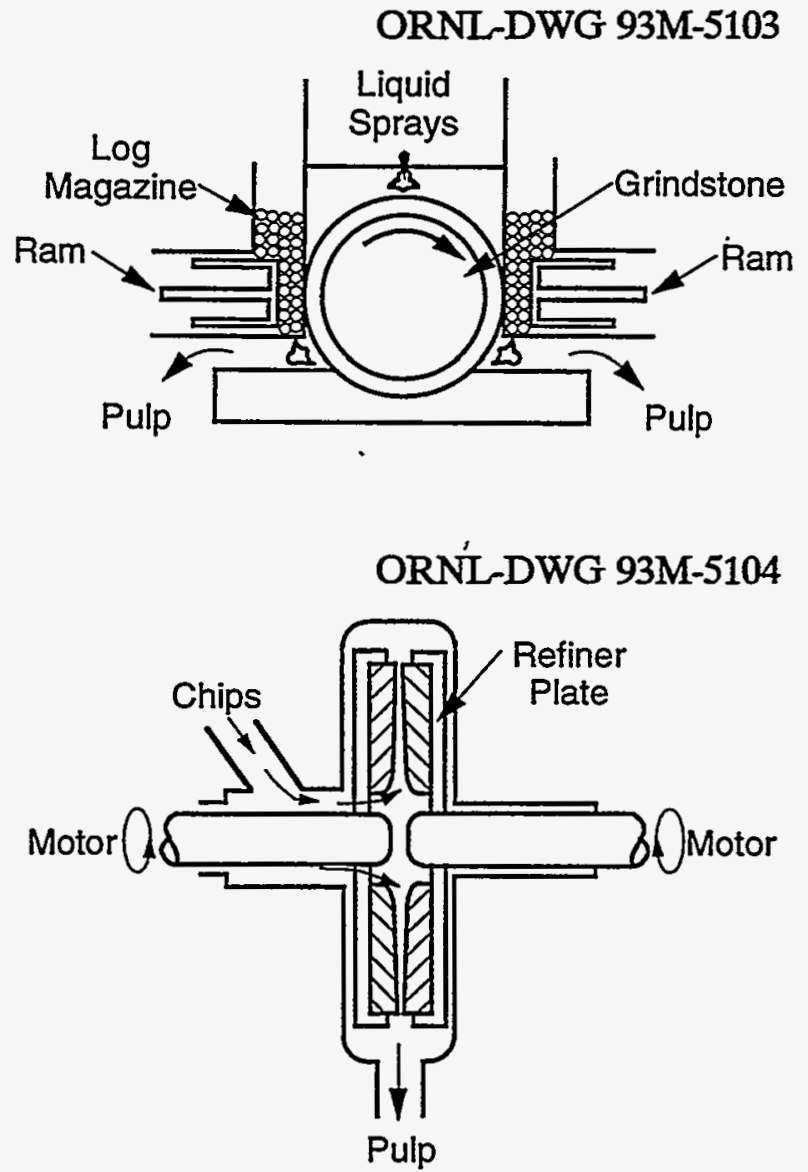

(b)

Figure 1. Schematic diagram of

(a) groundwood machine and (b) disk refiner (from Metals Handbook).

rotation axis and are reduced to fibers as they move radially through the gap. The faces of the disks are covered with plates containing raised bars $(3 \mathrm{~mm} \mathrm{x} 6 \mathrm{~mm} \times 25 \mathrm{~cm}$ ), the bars being large near the entry point of the chips, and increasingly finer as the outer radius of the plate is approached. Plates spin at $-1800 \mathrm{rpm}$ with an axial gap of 0.5 to $1.2 \mathrm{~mm}$. Refiners are usually powered by electric motors of up to 30,000 to $40,000 \mathrm{hp}$. Water is introduced with the chips in order to prevent oxidation of the wood. Refiner plates can be either cast or wrought, but most are cast. The alloys used are generally a white cast iron or cast stainless steel.

\section{Issues}

Corrosion associated primarily with presteaming, condensates containing sulfur-bearing acids and chlorides, and wear of refiner plates affect pulp quality and process efficiency. Pounding of the bar edges results in lessening of the refining capability of the system. Pitting of the bars by cavitation erosion is a major factor affecting materials selection for disk refiners. In addition, dashing of plates which can occasionally come in contact due to inadequate clearance (with the resultant formation of grooves and serrations on the face of the plates) is a severe issue. 
Improved materials or surface treatments which provide extended bar life and resist contact damage are important development needs for refiner plates.

Larger diameter, higher speed refiner operation is also a goal for current and future systems because of the energy benefits involved. Lighter weight refiner plate materials suitable for higher rotation rates would tend to decrease the stresses on the disks. At higher rotation rates, fracture toughness of the refiner disk materials is also a very significant issue. If cracks occur in the disks, they may grow rapidly resulting in catastrophic failure and significant damage to the systems. Life prediction modeling of these systems is extremely important in order to minimize risk of materials failure and downtime. At increased system throughputs and greater rotation rates, cavitation between refiner plates may also become more severe, and greater cavitation resistance may be necessary in the plate materials.

The incorporation of advanced ceramic materials may yield improved component lifetimes in mechanical or refiner pulping operations. This is especially true for the refiner plates, where there has been discussion of the use of tungsten carbide plates. Although this material is much more resistant to wear than the currently used metals, its density is so high that, at the higher speeds currently in vogue, the rotational energy involved would be excessive. Consequences of a catastrophic failure are serious at these energy levels. The use of ceramics, which are less dense than the metals currently used (especially the tungsten carbides) would provide greater wear resistance, use less energy, and have less dangerous consequences during failure. Several tough ceramics such as partially stabilized zirconias with $\mathrm{K}_{\mathrm{Ic}}$ values over $25 \mathrm{MPa} \sqrt{\mathrm{m}}(23 \mathrm{ksi} \sqrt{ } \mathrm{in}$.) have recently been developed and may have the required durability.

\section{CHEMICAL PULPING}

The predominant chemical pulping process used in the United States is the Kraft process. The Kraft process incorporates a system to recover the sodium hydroxide and sulfide, burn off the lignin and other organics, and at the same time provide steam and electrical power. This is done by separating out the pulp from the slurry and injecting the concentrated residual liquid (black liquor) into a recovery boiler where it is burned. Some of the sodium and sulfur follows the gas path as fume, deposits on upper heat-transfer surfaces, is separated in the electrostatic precipitator, and some is captured on the bottom of the boiler as sodium carbonate and sodium sulfide, which form as a molten stream ("smelt") at the bottom of the boiler. There are three main areas in the chemical pulping process: the digester (see Fig. 2), and the recovery boiler and the chemical recovery system (see Fig. 3) [from Metals Handbook]. Current materials of choice are carbon steel for nominal service and type 304 for cases where high-velocity streams are involved. The limits of steels to handle chlorides in alkaline sodium sulfide solutions are of concern due to the buildup in the concentration of these chemicals. Extended delignification processes involve adding more sodium sulfide and sodium hydroxide partway through the process, resulting in the possibility of increased corrosion or stress corrosion cracking.

Materials issues are mainly related to corrosion, especially in the boiler itself where elevated temperatures and highly corrosive species abound. Heat-exchanger tubes carry water into the boiler for heating, and these must not be allowed to leak or burst, as the smelt/water reaction can be explosive. It is therefore critical that tube leaks be prevented in the boiler. 


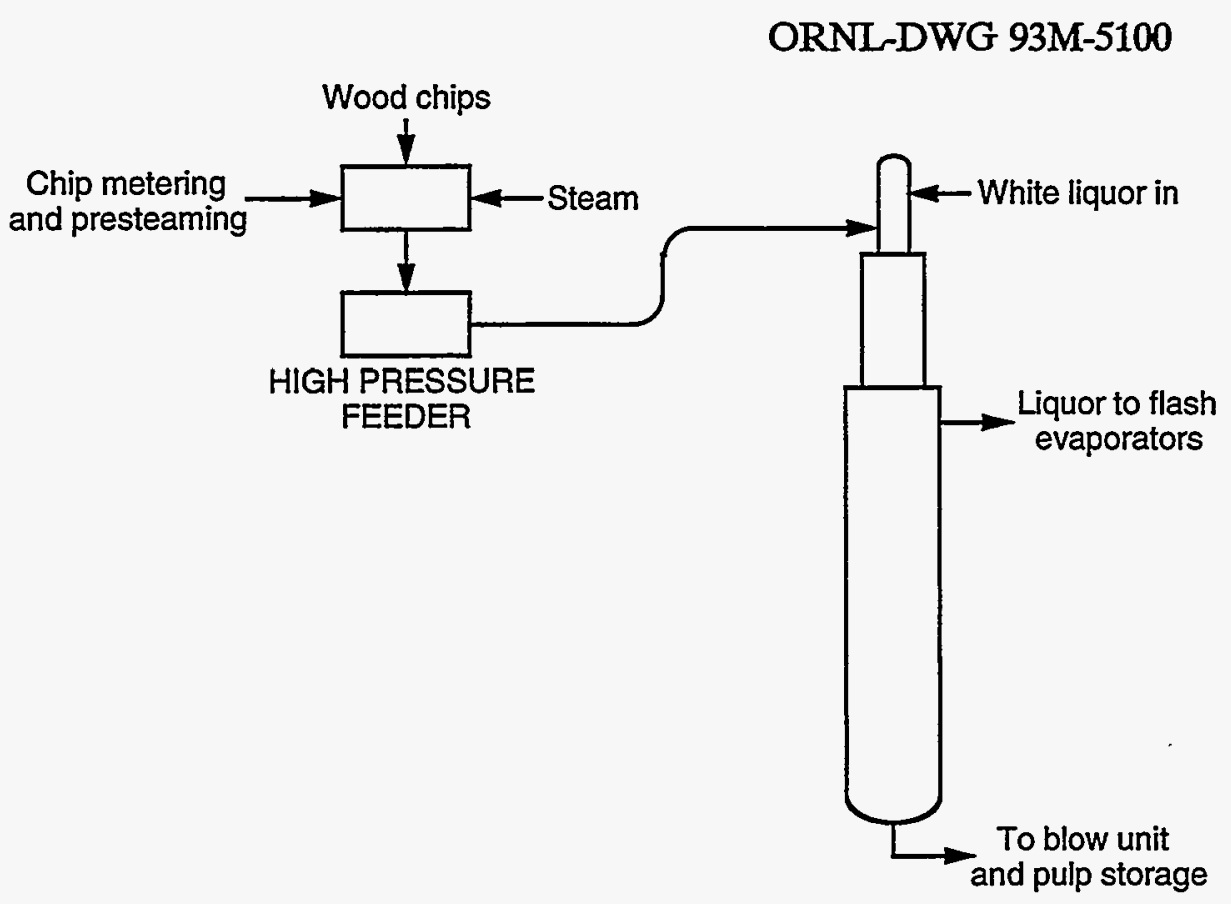

Figure 2. Schematic diagram of digester.

ORNL-DWG 93M-5101

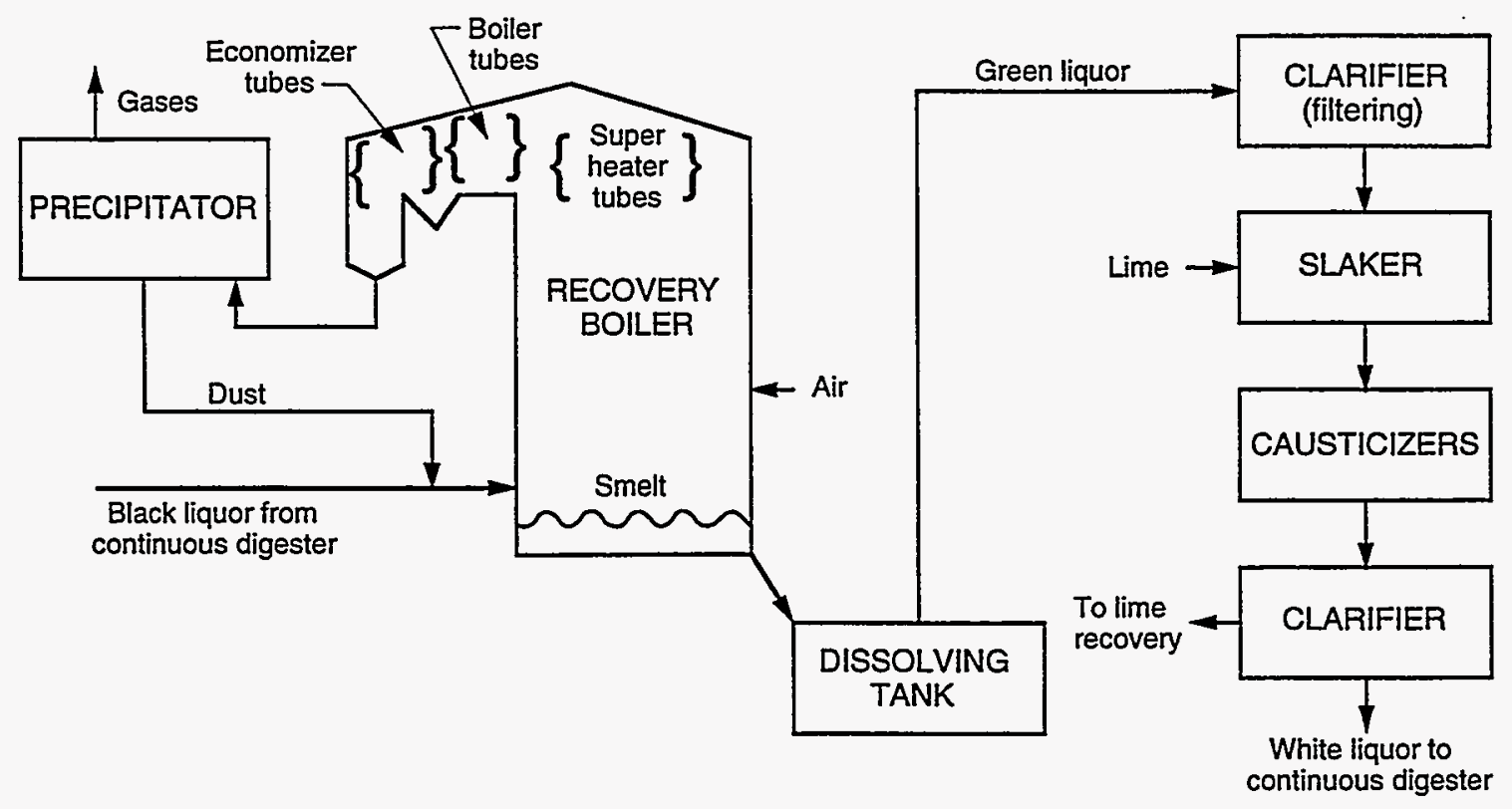

Figure 3. Schematic diagram of the recovery boiler and the chemical recovery system. 


\section{Digester}

In the digester, an alkaline sulfide liquor dissolves (digests) the lignin from wood fibers in a batch process or a continuous process. After digestion, the treated chips pass through a washing and cooling zone. The spent pulping solution (black liquor) is extracted from the top of this zone, and the chips are extracted from the bottom of the zone through a blow valve to the blow tank. The release and impact fiberize the chips. After leaving the digester, the black liquor is concentrated to $60 \%$ solids in multiple evaporators.

Issues

Adding a second point of introduction of the delignification chemicals in the digester tank can cause significant changes to the material behavior and requirements. For example, introducing pulping chemicals in the middle of the digester tanks could lead to enhanced corrosion effects. Carbon steel would probably not be sufficient, and even type 304 stainless steel may undergo stress corrosion cracking. Corrosion/erosion of metallic components including pipes, valves, pumps, etc., by sodium hydroxide/sulfide slurries also occurs.

With an appropriate filter, it should be possible to easily, rapidly, and economically remove a significant fraction of the liquid from various process washings and from black liquor. The filters would be metal-based and are expected to be easily cleaned by vibration or back-flushing. These filters will have a very long lifetime, and the waste stream will be reduced by many orders of magnitude. Reverse osmosis membranes may also be useful as they would require less than onehalf the energy required by multiple-effect evaporation.

Significant wear may occur in the blowdown vessel for the digested pulp. The target plate of the blow unit, upon which the digested pulp/slurry is directed, experiences the most significant wear problem.

\section{Recovery Boiler}

The boiler is used to incinerate black liquor while providing steam for cogeneration and plant processes. The main by-product of the recovery boiler is $\mathrm{CO}_{2}$. Smelt, consisting principally of molten $\mathrm{Na}_{2} \mathrm{CO}_{3}$ and $\mathrm{Na}_{2} \mathrm{~S}$, is formed at the bottom of the boiler. If boiler tubes leak or burst, then there is a possibility for an explosion due to the stream reaction between water and the molten smelt. In the United States, there are 1 to 2 explosions per year due to this effect. Thus, the integrity of the pressure tubes is extremely important.

Recovery boilers are expected to operate $358 \mathrm{~d} /$ year with about a 1-week downtime for servicing. About $50 \%$ of the mills in the United States have only one boiler. This means that if the boiler is not operating, the entire mill is shut down.

One of the developments which has occurred over the last 10 years has been the introduction of composite tubes (stainless-steel-clad carbon steel tubes developed and evaluated previously in Europe) in the boilers. Prior to that time, the material of use was carbon steel which had 2 -cm studs on the outer surface to enhance the attachment and solidification of smelt onto the tube in order to provide corrosion protection. Spray metallized tubes have also shown limited success. The lifetime of the metallized layer ranges between 3 to 5 years; however, corrosion 
products and tube cleaning processes tend to remove the protective coating. Composite tubes have solved many of the corrosion problems except at the port openings.

The operational characteristics of these recovery boilers are different from utility boilers. There is:

1. more material deposited on the surface of tubes, leading to reduced heat transfer (but in the lower part of the furnace, these deposits keep the tubes cool and corrosion rates low);

2. localized thinning and erosion of tubes due to the presence of particles (sulfides) in the gas streams;

3. molten salt corrosion attack of materials; and

4. lower superheat temperature [pulp and paper $\sim 480^{\circ} \mathrm{C}\left(900^{\circ} \mathrm{F}\right)$; utility $-540^{\circ} \mathrm{C}\left(1000^{\circ} \mathrm{F}\right)$ ].

Limitations are due to molten chemical attack of tubes in the superheater section of boilers. The maximum steam temperature is kept low enough to prevent corrosion in the superheater tubes due to melting of salt deposits and resultant molten salt corrosion. Salt deposits melt at temperatures between $510^{\circ} \mathrm{C}\left(950^{\circ} \mathrm{F}\right)$ and $565^{\circ} \mathrm{C}\left(1050^{\circ} \mathrm{F}\right)$.

\section{Issues}

The most challenging materials problems stemming from this process are associated with processing the spent (black) liquor. Typical problems include attack on the fireside of boiler tubes associated with molten salts, corrosion of water tubes in lower furnace sections under a frozen smelt layer, corrosion of the smelt spout, and stress-assisted corrosion on the waterside of boiler tubes. The use of uncooled ceramic spouts (given proper thermal shock, toughness, and other properties) may result in improved corrosion resistance and avoiding the risk of explosions.

Localized corrosion occurs at the air inlet ports normally located near the bottom of the boiler. Corrosion of stainless and nickel-base materials also occurs. The corrosion effects need to be determined and improvements made in materials and design.

Because it is so important that the boiler tubes not leak, a means of monitoring and measuring the thickness of tubes is required. Such a system would be extremely useful as a means to reduce accidents and resulting downtime. The current procedure is to develop a grid of points which can be checked with hand-held ultrasonic testing equipment.

Waterside corrosion fatigue cracking of materials (stress-assisted cracking) occurs in the lower part of the furnace, generally near weld attachments. Fissures grow underneath external welds from inside the tube to the outside. The mechanism responsible for this phenomenon needs to be determined and life prediction models developed. In addition, improved nondestructive evaluation methods need to be developed to detect waterside stress corrosion cracking. Current X-ray instruments cannot access needed locations without stripping off refractory.

Methods and devices for detection of external cracking of composite tubes located in the lower part of the furnace are needed. Cracks tend to grow and form through the stainless layer. The 
cause of the cracking needs to be determined and materials evaluated under various environmental conditions. External cracking of the composite tubes in the lower furnace due to stress corrosion cracking or thermal fatigue cracking results in significant downtime and repair costs.

Thermal fatigue cracking has also been found in composite tube butt welds in the lower furnace walls. Cracks extended approximately $0.5 \mathrm{~mm}$ into the carbon steel portion of the weld. Cracks were present in tubes at locations between 1 and $10 \mathrm{~m}$ from the bottom of the boiler.

Thermal fatigue cracking of composite tubes has also been found at the spout openings and at the liquid smelt-gas interface near the bottom of the boiler. Many tubes crack at a level between 2 to $5 \mathrm{~cm}$ above and below the normal location of the liquid smelt level. Since repair of the tubes is difficult and tubes would normally be replaced if cracked, one solution is to use metallized sections initially. More extensive testing of the integrity of tubes, however, is required.

Refractory coverings on the floor of the furnace are being evaluated to reduce exposures of the floor tubes. Ceramic tiles, tested in boilers, have buckled up to $50 \mathrm{~cm}$ above the floor level. High-alumina refractories corroded in less than 1 year.

Another option which has been available to industry for many years is chromized tubing for both the superheater section and the lower part of the boiler. A diffusion coating is used and the chrome replaces the iron in the material. There is a high percentage of chromium on the surface of the tube ( 30 to $50 \%$ ), but the $\mathrm{Cr}$ concentration decreases rapidly, the depth being only $\sim 0.2 \mathrm{~mm}$. Some chromized superheater tubes have experienced severe pitting. Concerns regarding chromized tubes include loss of coating by erosion or mechanical cleaning and the inability to detect fractures or penetrations in the coating layer.

Significant materials issues also exist in recovery boiler superheater tubes. These tubes encounter the hottest environments and are often alloyed for corrosion resistance. If process conditions form molten deposits on the surfaces of tubes, attack is extremely rapid. In some cases, type $310 /$ carbon steel composite tubes have been installed.

\subsection{Chemical Recovery System}

The smelt, consisting primarily of $\mathrm{Na}_{2} \mathrm{CO}_{3}$ and $\mathrm{Na}_{2} \mathrm{~S}$, is dissolved in water to make "green liquor." This solution is causticized with slaked lime to convert $\mathrm{Na}_{2} \mathrm{CO}_{3}$ to $\mathrm{NaOH}$, and the resultant "white liquor" is returned to the pulp digester.

\section{Issues}

More conventional corrosion problems are associated with the processing of the green and white liquors, including caustic corrosion and cracking, sulfur acid-induced wastage, acid-cleaning of heat-exchanger surfaces, and corrosion/erosion caused by steam impingement.

\subsection{New Processes}

Several new pulping processes are under evaluation, most of which are of the "chemical" variety. They are largely aimed at eliminating the environmental problems associated with the use of 
sulfur-containing chemicals. Sodium-bearing species are involved in some of these processes, as in the soda-anthraquinone process. Other processes utilize enzymatic, biological, or organic acid solvent attack on the wood structure to accomplish the pulping, and the corrosion consequences of these processes are not yet fully explored.

Black liquor gasification is a new process wherein the liquor is not burned in a recovery boiler but pyrolyzed and reacted with steam to form a fuel gas and inorganic salts. The MTCI pulseenhanced steam reformer consists of multiple resonance tube pulse combustors with the resonance tubes immersed in a bubbling fluidized bed reactor. The heat required for gasification is provided by burning a portion of the product gas in the pulse combustor and transferring heat through the resonance tubes into the fluidized bed.

The major benefit associated with the MTCI process is that the inorganic salts are recovered in solid form (i.e., no melt is formed). The solid inorganics are dissolved to produce a sodium carbonate solution that is used to remove hydrogen sulfide from the raw product gas, thereby producing green liquor for return to the pulping process.

A wide range of biomass materials has been successfully converted in laboratory experiments. A large-scale pilot facility has been operated using rejects from a recycle mill as its feedstock. A near-commercial-scale facility for processing black liquor is under construction.

Economically useful gases may be separated from gasified black liquor. Development work is currently in progress to fabricate inorganic membranes to separate hydrogen from gasified coal at temperatures of $700^{\circ} \mathrm{C}\left(1300^{\circ} \mathrm{F}\right)$ to $1000^{\circ} \mathrm{C}\left(1830^{\circ} \mathrm{F}\right)$. Such membranes will be useful because more hydrogen is produced from the black liquor than is needed for the combustion process. The process economics could perhaps be improved by separating some of the hydrogen for sale as a separate product. There may be other valuable gases that could also be separated for sale as a marketable product.

\section{Issues}

Recycling of process streams can affect the corrosion behavior. For example, the concentrating effect of various processes leads to an increase in the thiosulfate concentration and also the concentration of chlorine in the liquids. Development of an economical process to remove chloride salts from the liquor cycle would be of great benefit.

Advanced processing methods can also lead to significant effects related to materials. Materials selection and needs must be introduced early in the process to enable the process to be successful and not result in failure or dangerous situations. Sulfur-free pulping, for example, can result in a more bleachable pulp and reduce the concentration of sulfur-bearing emission gases.

Materials issues with respect to black liquor gasification processes include sulfidation and/or alkali corrosion of metal tubes immersed within the bed, tube erosion, and refractory life.

Membranes may enable the separation of black liquor into a source of economically useful chemicals. Black liquor is such a complex mixture that, to date, no economical method has been found to achieve the separation. It should be possible to fabricate inorganic membranes with graded pore sizes that could be used to separate fractions of the black liquor containing different 
size chemical molecules. In addition, membranes may also be used to improve the quality and Btu content of gases produced from new black liquor gasification processes.

\section{RECYCLED PAPER SYSTEMS}

Much paper is recycled, especially newsprint, with the amount incorporated into the new paper being a function of many variables. These include the type of fibers (most may be recycled only a few times before losing significant strength and causing loss of quality of the new paper), the amount available, local regulations, etc. The operations involved are separation out of contaminants (rocks, wire, etc.) and improper paper types, de-inking, and shredding/digestion.

Recycling of post-consumer paper products constitutes an ever-increasing source of the pulp used in the U.S. papermaking industry. However, the paper generally comes from varied sources, and the identity of the inks is unknown. There are problems with deposits of the inks on equipment. Chemicals used to remove ink from fibers cause a strength degradation to occur. Material from de-inking can account for as much as one-fourth of the volume of received recycled paper.

\section{Issues}

Wear problems may be particularly severe in the handling of recycled paper products which may be contaminated by abrasive materials, metal shards, and other debris harmful to the processing equipment. De-inking involves the use of chemicals that are relatively aggressive to metallic containment systems. Materials issues in these operations are again erosion and corrosion, sometimes aggravated by unwanted biological growths brought in by recycle paper.

Other key issues include effects of incineration on materials, removal of heavy metals from solutions, and safe landfill disposal and treatment of wastes.

\section{MATERIALS REQUIREMENTS}

Mechanical Pulping

- Improved ceramics for rotating grindstones

Mechanical Refiner

- Lighter weight metals, ceramics, and composites for high-rotation-rate refiner plates

- Surface treatments (hard surface on ductile matrix) to improve wear and cavitation resistance and to increase toughness of refiner plates

- Corrosion/erosion testing of candidate refiner plates in the presence of steam and cavitation

- Improved bearing materials and failure diagnostics for disk refiners

Digester

- Digester vessel liner/weld overlay materials to combat caustic stress corrosion cracking and corrosion from caustic sulfide solutions 
- Modeling of digester corrosion processes to optimize design and operating parameters

- Improved target blow plate materials to resist corrosion, cavitation, and wear by effluent from the digester

\section{Recovery Boiler}

- Sulfidation-resistant superheater and reheater tube materials and coating systems (including ceramics) to attain higher steam temperatures

- Studies of corrosion mechanisms leading to stress-assisted corrosion of water-wall tubes

- Sensors to monitor thinning and degradation of recovery boiler tubes

- Recovery boiler tube materials with improved resistance to stress-assisted waterside corrosion and fireside attack by pyrosulfates or other molten salts, molten sulfates, or pyrosuifates

- Abrasion-resistant materials for handling recycled paper

- Corrosion thermal shock and impact-resistant ceramics for uncooled water-free smelt spouts

New Processes

- Assess corrosion processes in gasifiers being developed for recovery of black liquor chemicals

- Membranes to improve the quality and Btu content of gases produced from black liquor gasification processes

- Process or materials to remove chlorides and potassium from the liquor cycle

\section{BLEACHING}

Pulps vary considerably in their color after pulping, depending on the wood species, method of processing, and extraneous components. For many paper types, particularly printing grades, the digested wood pulp is subjected to various oxidative (oxygen, hydrogen peroxide, or ozone) or chlorine-containing chemicals to effect an increase in the brightness or whiteness. There are basically two types of bleaching operations: those that chemically modify the chromophobic groups by oxidation or reduction but remove very little lignin or other substances from the fibers, and those that complete the delignification and remove pitch and some carbohydrate materials. The processes take place at low temperatures, inasmuch as the cellulose fibers are in waterborne suspension.

Materials issues are largely related to the corrosiveness of the chemical solutions, some of which are at $\mathrm{pH}<2$, others at $\mathrm{pH}>12$. Metals, as well as fiber-reinforced plastics, are utilized routinely. 


\subsection{CURRENT BLEACHING METHODS}

Bleach plants have become more corrosive over the past 20 years as mills have "closed" wash water systems and reduced effluent volumes. Many mills have turned to higher alloy stainless steels, nickel-base alloys, and titanium for better corrosion resistance. Metals are chosen over nonmetals for moving equipment, such as washers. Metals are stronger, tougher, have better fatigue properties, and, if they have sufficient corrosion resistance, require virtually no maintenance. However, the more corrosion-resistant alloys are more costly, and the challenge is to choose an alloy with just enough resistance to avoid corrosion problems.

\section{Issues}

Pulp mill bleach plants have traditionally used austenitic stainless steels because of their combination of good corrosion resistance and weldability. Current materials for bleaching equipment also include titanium alloys. Some issues include evaluating the behavior of titanium alloys in alkaline environments since titanium alloys have high corrosion rates in alkaline peroxides.

Concern over dioxins in effluents is mandating the switch from chlorine-type bleaching chemicals to oxygenated bleaching chemicals. Hot acid chloride solutions are difficult for certain types of steels to handle. There has been significant concern about titanium in alkaline peroxide solutions. Substitution of chlorine dioxide for chlorine does decrease effluents, but it also increases corrosion problems. New bleaching using superoxygenated compounds may shift corrosion problems to polymer materials rather than metals. There are no data on how these plastics will perform in the presence of superoxygenated compounds.

A low-pressure drop-cleanable filter can be used to easily, rapidly, and economically remove a significant fraction of the bleach from the pulp. Multiple washing cycles can be used to reduce the concentration of the bleach in the pulp to the desired level. Reverse osmosis can be used to separate concentrated chlorinated waste liquors in order to reduce corrosion problems in pulping systems. This will contribute significantly toward having an economical closed-cycle system for the pulp operation. The bleach can be concentrated, removed, purified, and returned to the bleaching cycle. The water removed from the bleach solution can be recycled for multiple washings to reduce the amount of bleach remaining in the pulp. This will contain most of the bleach in the bleach cycle and significantly reduce the potential for corrosion in other parts of the processing plant.

\subsection{NEW PROCESSES}

Because of the large amount of water required to be removed from the dilute bleaching slurries and the incompatibility of the chlorine-containing chemicals with other process streams at the paper plant, many alternative bleaching processes are being evaluated. The main driver of change in the bleaching operation, however, is the need for reduction of the amount of chlorinated organic compounds to minimize the consequences of disposal or release to the environment of these troublesome materials. These alternative processes may utilize oxygen, ozone, or chlorine dioxide. This change from chlorine compounds to oxygenated materials for bleaching should lessen the corrosion problems for metals. Technological questions related to joining and long-term structural integrity are also issues which need to be resolved. 
$\underline{\text { Issues }}$

The new superoxygenated bleaching processes are thought to be less corrosive; however, the corrosion characteristics of various materials are not known. The use of polymers should be explored. However, there are almost no data on these materials. Another aspect to the low use of polymer-based material relates to industrial acceptance of unfamiliar materials.

The substitution of chlorine by chlorine dioxide is another process change which can substantially affect the behavior of materials. Chlorine dioxides can lead to higher corrosion rates. Even some of the most advanced nickel-base alloys are at their limit when chlorine dioxide is present in the pulp.

The wide range of chemical conditions and the use of species which are aggressively corrosive suggests that there may be certain specific applications where ceramic materials would prove effective. These would most likely be in the form of coatings on the vessels and piping, valves, etc.

\subsection{MATERIALS REQUIREMENTS}

- Evaluation of currently used austenitic stainless steels and titanium alloys in peroxide and $\mathrm{ClO}_{2}$ environments

- Identification of new alloys better able to withstand corrosion caused by oxygenated bleaching materials

- Corrosion-resistant weld filler materials and improved welding practices

- Evaluation of ceramics, ceramic coatings, and polymeric materials as replacements for metallic alloys in some applications

- Cleanable filters and membranes to separate bleach from pulp

\section{PAPERMAKING}

The pulp fibers in suspension are concentrated to the desired degree and fed into a box (the headbox) which contains a slit opening. The slurry is metered out of the slit (slice) onto a plastic (nylon or polyester) mesh "wire." A wet paper web is formed by drainage of the majority of the water from the slurry. The wet paper web is then transferred onto a "felt" and pressed between rolls to achieve further dewatering by mechanical pressure. The paper web is then transferred by the "felts" to the dryer section where it is dried in contact with a series of hot, steam-heated rolls. Coatings may be applied to the dry paper sheet at the dry end. The paper is cut (slit) with knife blades as required for proper sizing. A schematic diagram of the papermaking line is shown in Fig. 4.

The corrosion characteristics of this unit process can be fairly benign with the $\mathrm{pH}$ ranging from 4 to 10 , the $\mathrm{O}_{2}$ level as well as the dissolved salts concentration being low, and the chlorine 
ORNL-DWG 93M-5102

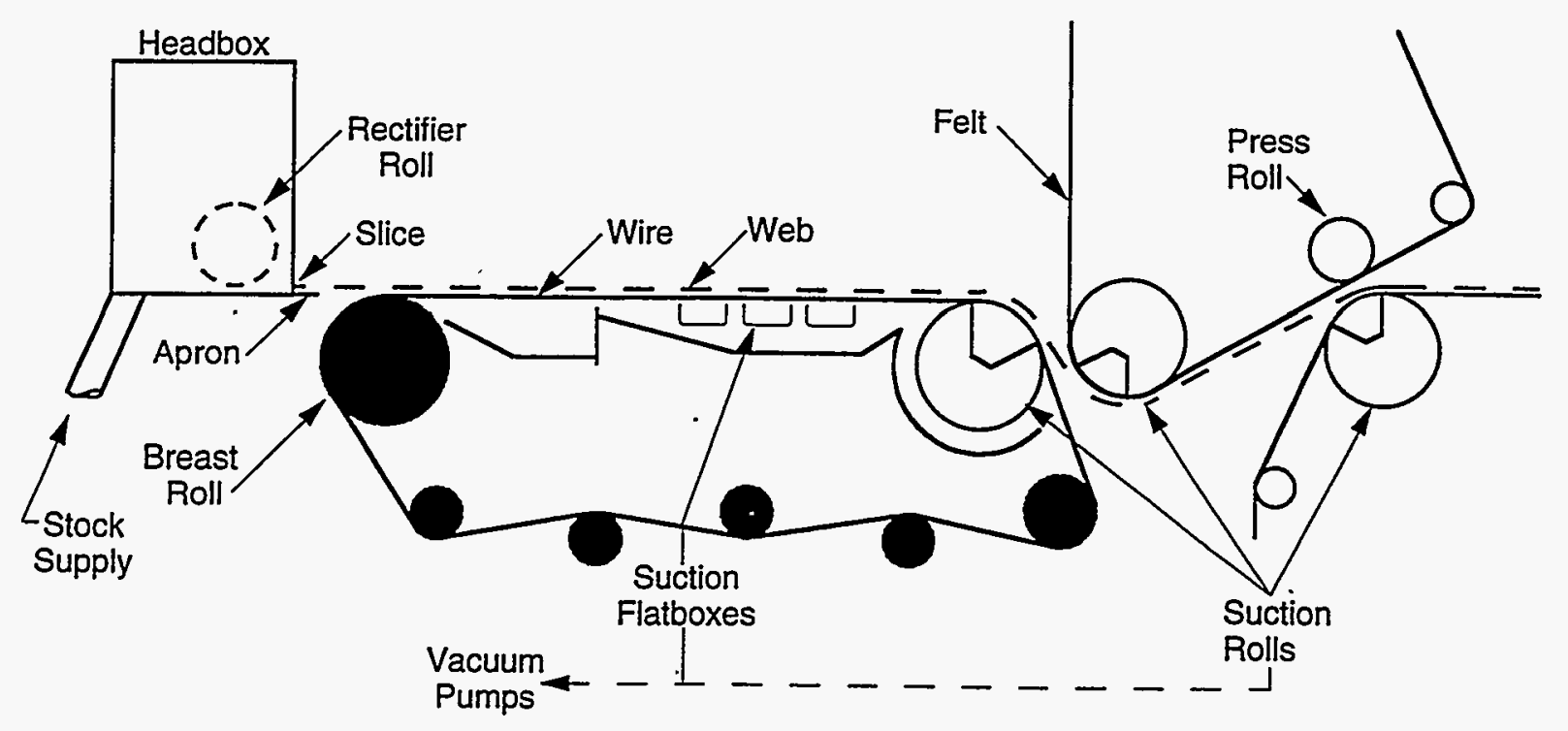

Figure 4. Schematic diagram of headbox and forming section of a paper-making machine (from Metals Handbook).

concentration in the low ppm range (typically 20 to 50 ppm for bleached pulp). Current materials used include carbon steel, stainless steel, and nickel-base alloys.

Other general issues include iron deposits which may discolor paper and microbial deposits which may affect the quality of the paper.

\subsection{STOCK PIPING AND HEADBOX}

Structural materials of the headbox and rolls are nearly all metallic. The slurry is often supported on an organic (plastic) webbing material or on an organic felt.

Corrosion levels are generally low. However, in closed systems, severe corrosion problems may develop due to increased thiosulfate levels, especially for carbon steel parts. Corrosion may occur on the slice lips of the headboxes. Fiber deposits found on the slice lips of the headboxes may contain a high concentration of chloride and lead to severe corrosion, which may require replacement of carbon steel parts with nickel-base alloys.

\section{$\underline{\text { Issues }}$}

Materials issues involve corrosion and erosion/abrasion, as the solution carrying the cellulose fibers still contains several chlorine-containing compounds. These may cause pitting attack on metals, particularly where surface deposits form on such areas as the slit orifice and the rolls, and in the latter case may lead to catastrophic failure and costly subsequent paper line shutdowns for replacement. Durability of components in the headbox is an area where improvements may be made. 
There are many applications where ceramic components may be introduced into this unit operation including the slit edge in the headbox, the knife edge on the coater, the slitter knives, and perhaps as rolls or roll coatings. However, the large size of rolls will present a challenge to ceramic manufacturers. Ceramic bearings for long life at high speeds in poor lubrication environments may also yield improvements. Several advanced ceramic bearing materials are now in production, all based on silicon nitride. Bearings made from these materials are finding use in extreme environments in high-speed machine tool spindles, where they allow speeds impossible with metallic bearings, because the oil lubrication is spun out of the bearing race. Papermaking machine screen baskets, which are subject to corrosion fatigue and corrosion erosion, appear to be a good application for ceramic fiber composites.

\subsection{INTERMEDIATE STRUCTURES/DRYERS}

Intermediate structures in the papermaking line including rolls, webs, felts, wires, etc., are designed to create undamaged paper pulp web and to remove as much water as possible before entering the dryer section.

Suction rolls draw water from the paper by vacuum. These rolls are probably one of the highest cost capital equipment items in the pulp and paper plants. Their cost is approximately $\$ 1$ million each.

Paper is dried by passing it through top and bottom rolls. The rolls are heated with steam and are normally made from cast iron. Metallic and microbiological deposits are of concern from the viewpoint of paper discoloration. Opportunities exist for improved materials which are not as brittle or that are lighter than the present materials.

The critical properties which felts must possess include the ability to hold water and the ability to prevent rewetting of the paper. Currently, felts are made from needle-punched non-woven nylon with possibly some other polymeric fibrous materials. Wires are usually made from nylon. The type of weave is also important in determining the durability of the wire. A set of felts on typical papermaking machines costs approximately $\$ 30,000$ each and is generally replaced once per month and drying fabrics every 6 months.

\section{Issues}

Increasing quality, minimizing waste, and process control lead to the need for improved materials in both the process equipment and sensing devices. A need also exists to improve and control the distribution of pulp on the wire mesh belt. In addition, microbiological deposits need to be controlled since dislodged deposits can cause damage to the paper web.

The need exists for felts and wires to be more wear resistant and be able to operate at higher temperatures. At the present time, the thickness of the outermost fiber in contact with the rolls and ceramic plates is measured as a way of determining the necessity to replace the felt.

Suction rolls are typically made from hardenable duplex stainless steels and are subject to corrosion fatigue cracking. Cracking is sometimes traceable to cosmetic weld repairs, to defects in the casting, and to drill holes. Needs exist for alloys with improved corrosion and mechanical characteristics, manufacturing improvements in the casting process, and modeling. Suction rolls are very expensive, and failures occur due to cracking and corrosion. When these rolls fail, much 
damage may be done to adjacent parts of the papermaking machine. When dryers fail, 3 or 4 other dryers may be damaged. New versions of suction rolls are being introduced, and innovations are concentrating on structure and new alloys.

\subsection{PAPER FINISHING AND HANDLING}

Coatings are applied at very high speeds to various types of paper products. For example, clay, latex, and whitening agents are applied to paper to produce printing surfaces. Typically, the speed of the paper through the machines depends on the product type being produced. For example, newsprint may be produced at a speed of $7.5 \mathrm{~m} / \mathrm{s}(1500 \mathrm{ft} / \mathrm{min})$ to $25 \mathrm{~m} / \mathrm{s}(5000 \mathrm{ft} / \mathrm{min})$. However, the speed of paper which is coated is in the range of 2000 to $3000 \mathrm{ft} / \mathrm{min}$ on the machine.

\section{Issues}

The efficiency and uniformity of applying the coating is an opportunity for improvement. The clay-bearing solution must be uniformly distributed on the take-up roll without having skipped regions. The clay solution must then be uniformly transferred and applied to the paper supported by a backing roll. The interactions of the doctor blade with the backing roll must also be considered. There is also a need to understand the fundamentals and dynamics of the process to improve efficiency.

\subsection{NEW PROCESSES/GENERAL ISSUES}

The impulse drying process under development at the Institute of Paper Science and Technology employs a heated roll press to activate a more efficient water removal mechanism. During the process, wet paper is brought into contact with a hot-press roll, typically heated to between $200^{\circ} \mathrm{C}\left(400^{\circ} \mathrm{F}\right)$ and $400^{\circ} \mathrm{C}\left(700^{\circ} \mathrm{F}\right)$, while pressures between $3 \mathrm{MPa}(400 \mathrm{psi})$ and $5 \mathrm{MPa}$ ( $700 \mathrm{psi}$ ) are maintained in the sheet for times between 15 to $30 \mathrm{~ms}$.

\section{Issues}

Durability of ceramic coatings on steel rolls in impulse dryers is a concern. Good wear resistance is required. Current operating temperature is approximately $200^{\circ} \mathrm{C}\left(400^{\circ} \mathrm{F}\right)$. Higher temperatures, $260^{\circ} \mathrm{C}\left(500^{\circ} \mathrm{F}\right)$ to $315^{\circ} \mathrm{C}\left(600^{\circ} \mathrm{F}\right)$, and pressures are desirable. The survivability of the ceramic coatings needs to be tested. Ceramic coatings need to be applied to full-size rolls to evaluate the materials, coating technology requirements, and the behavior of the rolls tested in a pilot facility. Alternate ceramic materials coatings and application methods need to be evaluated.

The ceramic coated steel roller requires a lubricated hydrostatic element located inside the roll. This element must have good wear resistance at high temperatures, $260^{\circ} \mathrm{C}\left(500^{\circ} \mathrm{F}\right)$ to $315^{\circ} \mathrm{C}$ $\left(600^{\circ} \mathrm{F}\right)$. Scaleup will result in higher loads on presses, increased demand on lubrication, and increased wear. Felt properties also influence impulse drying efficiency.

Roll pressure shoes are of various sizes. However, a typical shoe has a pressure-bearing length of approximately $50 \mathrm{~cm}$. This may result in pressures in the $14 \mathrm{MPa}(2000 \mathrm{psi})$ range on the rubber rolls and presses. 


\subsection{MATERIALS REQUIREMENTS}

- Materials with improved abrasion resistance for doctor blades, slitters, drums, and screen baskets

- Improved lubricity between the pressure shoe and the roll

- Materials with improved corrosion fatigue resistance for headbox components

- Materials with improved wear and/or corrosion resistance for press rolls

- Surface treatments to control residual stresses and improve corrosion fatigue properties of suction rolls

- Structural analysis and design modifications to reduce cyclic loading

- Cast stainless steels with improved stress-corrosion resistance

- New ceramics or ceramic coatings with improved resistance to cleaning chemicals

- Life prediction modeling

- More ductile replacement for cast-iron dryer rolls

- Higher modulus (stiffness) material for impulse dryer rolls

- More durable felts and wires

- Improved, high-performance oils and greases for bearings

\section{OTHER TECHNOLOGIES}

\subsection{MOTORS/GENERATORS/TURBINES}

The paper and pulp industry is a significant user of power but also supplies, through cogeneration, a significant percentage (58\%) of its power needs. Energy conversion efficiency is very important for the overall economics of papermaking. Utility power quality and energy conversion efficiency affect all paper and pulp unit operations from the wood yard, to papermaking, to environmental/waste minimization.

\section{Issues}

The pulp and paper industry's reliance on sensitive electronic systems for such important functions as data processing, communications, and process control has necessitated a new concern toward the quality of the electric power supply. Voltage sags are the most common power quality problem affecting facilities. Voltage sags occur during faults on the power system. Since 
these faults cannot be completely prevented, facilities must make sure their critical loads are not impacted by the resulting voltage. Power quality problems can produce significant cost, schedule, and performance impacts at paper and pulp facilities that require continuous power quality. The rapid response of a flywheel motor/generator system ensures no interruption of continuous manufacturing processes, electronic equipment, and computer facilities. The flywheel energy storage system has lower cost than comparable sized battery systems. Improved permanent magnets will also improve the overall round-trip efficiency of energy conversion. High-efficiency axial gap generators can improve the overall conversion efficiency of cogeneration systems. The high-efficiency axial gap motor can result in less power consumption compared to existing electric motors.

\subsection{SENSORS AND CONTROLS}

Currently, the need for continuous on-line process sensors is great throughout the paper industry. Almost every aspect of the pulp and papermaking process could benefit from improved, on-line sensors and control systems. Several examples are listed below.

\section{Issues}

Because it is so important that the boiler tubes not leak, a means of monitoring and measuring the thickness of tubes is required. Currently, this is performed off-line by ultrasound. Coating deposits of smelt material on the tubes cause variations in the signals, and the method can produce misleading data if the tubes are very thin. It is these weak areas that need to be identified. In addition, the test is performed in a statistical manner which means that not all of the tube is inspected. A robotic device is needed to monitor the entire tube. The device on the outer part of the tube would have to meet stringent requirements since the space between tubes is limited and the surface is irregular due to surface deposits. Such a system would be extremely useful as a means to reduce accidents and resulting downtime.

Motor current analysis can be used to predict bearing failure.

Although paper strength requires off-line destructive measurements, stiffness can be determined on moving webs by measuring the velocity of ultrasound. Transducers mounted in fluid-filled wheels are used to make out-of-plane (two-dimensional) ultrasound velocity measurements on paper webs moving in the nip between two such wheels. Comparisons of the arrival times of echo and transmitted pulses with and without the paper web in the nip provide a measure of the transit time and caliper. Timing requirements are very stringent (in the nanosecond range), and variations in the roundness or thickness of the fluid-filled wheels lead to noise in the signal. Currently, the signal is integrated over one or more wheel rotations to minimize these effects.

The opportunities related to the fluid-filled wheels include improving roundness, thickness uniformity and radius, wear properties, and endurance.

In-plane ultrasound velocity measurements use bimorph transducers mounted in the surface of aluminum cylinders or rolls. The needs include improving the wear behavior of the transducers and improvement in the means for electrical and signal communication with sensors located on rotating rolls. At present, communication is performed by using slip rings. Other means of signal communication, such as fiber-optic methods, may be practical. 


\section{MATERIAIS REQUIREMENTS}

\section{Motors/Generators/Turbines}

- $\quad$ Pitting-resistant materials for scrubbers

- Sulfur-resistant materials for gas turbines

Sensors/Nondestructive Evaluation

- Robotic inspection techniques to evaluate boiler tube integrity

- Motor current analyses to predict motor/generator/bearing failures

- On-line sensors to measure moisture content, thickness, stiffness, web and paper quality, and fiber properties and orientation

- Improve properties of fluid-filled rubber rolls (roundness, thickness uniformity, and wear) used in stiffness measurements

- Improve wear behavior of slip rings

\section{ENVIRONMENTAL ASPECTS/WASTE HANDLING AND MINIMIZATION}

Environmental and energy concerns are playing an increasing role in the design and operation of paper and pulp mills. The short-term approach has been to add scrubbers, precipitators, holding ponds, etc., to control effluents. However, the longer-term solutions will invariably lead to major modifications of current procedures or replacement technologies (e.g., the minimization or elimination of malodorous sulfur compounds and chlorine). Plant "closure" is also leading to increased concentrations of deleterious chemicals, resulting in new and unexplored corrosion concerns.

There are several stages involved in waste processing and minimization. Issues are related to toxicity, color, etc. Reduction of these parameters can occur in biotreatment stages, but little is known about the specific bioprocesses that occur. For example, it is not known if nutrients should be added or specific compounds that are toxic to the waste treatment bacteria removed, etc. This is a wide open area, but little is known and little is being done. There may also be opportunities for novel separations techniques. Plants produce solid wastes that include heavy metals. These sludges are dewatered using a screw press. Currently, the waste is landfilled or burned.

\section{Issues}

Biotreatment processes are anticipated new technologies to treat waste, including sludges. Key issues include: (1) development of improved biotreatment processes, including the effects of specific biological bacteria, nutrients, environment, and removal of specific and general chemicals 
from the waste stream; (2) development of separations technologies including chemical, biological and physical separation methods; and (3) treatment of sludges. Sludges may contain elements that were absorbed by trees during growth and impurities introduced during the pulp and papermaking process.

Materials issues in these operations are again erosion and corrosion. Corrosion appears to be a larger concern, especially as the solutions are evaporated and the corrosion-inducing ions (chlorine, etc.) become more concentrated. The ash produced from incineration may also pose wear problems.

\subsection{MATERIALS REQUIREIMENTS}

- Membranes suitable for reverse osmosis or nanofiltration to separate volatile compounds

- Engineered porous materials for filtration of liquid waste streams

- Inorganic membranes to remove deleterious chemicals to reduce concentration and permit plant "closure"

- Improved, cavitation-resistant materials for pumps

- Materials with improved abrasion resistance in ash transport chutes and pipes

\section{WEAR}

From the harvesting of trees to the use of paper products in packaging and printing, wear and friction unquestionably are important issues for the pulp and paper industry. In the pulp and paper process, nearly every form of wear may be encountered: abrasive wear, erosive wear, wear by slurries, cavitation wear (in pumps), sliding wear, rolling contact wear, galling and scuffing, fretting wear, and impact wear.

Strategies for dealing with wear issues in industrial environments usually fall into the following categories:

1. accept the existing situation and plan for periodic maintenance to replace worn parts;

2. alter the process conditions to make the wear-producing environment less severe;

3. replace wear-critical portions of the machine with more durable parts, inserts, or surface treatments; and

4. replace the whole process or machine with one that does not have the same costly wear problems. 


\section{Specific Wear Problems}

As noted above, there are a great number of wear problems in the pulp and paper industry. Some of these are related to corrosive environments whose influence may accelerate the wear processes involved. Shown in Table 1 are several specific process areas and components where the wear behavior of materials is important to carry out the process, and opportunities for materials improvements exist.

Table 1. Wear - needs and opportunities

\begin{tabular}{|c|c|c|}
\hline Unit operation & Wear site/s & Opportunities \\
\hline Wood preparation & $\begin{array}{l}\text { Debarkers } \\
\text { Chipper } \\
\text { - cutting blades } \\
\cdot \cdot \\
\text { Log transport } \\
\text { - chutes } \\
\text { - blades } \\
\text { Saws } \\
\text { Knives } \\
\text { Slasher deck } \\
\text { - saw blades } \\
\text { Recycle paper handling }\end{array}$ & $\begin{array}{l}\text { Improved materials providing } \\
\text { greater impact-resistant edges for } \\
\text { chipper blades, saws, knives, and } \\
\text { slasher deck blades } \\
\text { Materials with improved abrasion } \\
\text { resistance for log transport chutes, } \\
\text { debarkers, and recycle paper } \\
\text { handling }\end{array}$ \\
\hline $\begin{array}{l}\text { Pulp preparation } \\
\text { (mechanical) }\end{array}$ & $\begin{array}{l}\text { Groundwood } \\
\text { Refiner } \\
\text { - disks/plates } \\
\text { - bearings } \\
\text { Digester blow plates } \\
\\
\text { Recovery } \\
\text { - pipes } \\
\text { - fluidized bed gasifier }\end{array}$ & $\begin{array}{l}\text { Improved ceramics for rotating } \\
\text { grindstones } \\
\text { Improved materials for refiner } \\
\text { plates providing extended bar life } \\
\text { and resistance to contact damage } \\
\text { Refiner materials suitable for } \\
\text { higher rotation rates with lower } \\
\text { mass and higher fracture toughness, } \\
\text { high-speed bearings } \\
\text { Materials providing improved } \\
\text { corrosion/erosion resistance for } \\
\text { digester blow plates }\end{array}$ \\
\hline Bleaching & Pumps & $\begin{array}{l}\text { Abrasion-resistant materials for } \\
\text { pumping high-consistency pulp } \\
\text { slurries }\end{array}$ \\
\hline
\end{tabular}


Table 1. (Continued)

\begin{tabular}{|c|c|c|}
\hline Unit operation & Wear site/s & Opportunities \\
\hline Papermaking & $\begin{array}{l}\text { Headbox (especially outer } \\
\text { section) } \\
\text { Fabric felt (knuckle) } \\
\text { Wire belts } \\
\text { Doctor blades } \\
\text { Knifes } \\
\text { Rolls } \\
\text { Slitters } \\
\text { Drums } \\
\text { Screen baskets } \\
\text { Impulse drying } \\
\text { - internal slider } \\
\text { Slip rings }\end{array}$ & $\begin{array}{l}\text { Materials with improved durability } \\
\text { for the header box and } \\
\text { intermediate structures } \\
\text { Materials with improved abrasion } \\
\text { resistance for doctor blades, slitters, } \\
\text { drums and screen baskets }\end{array}$ \\
\hline $\begin{array}{l}\text { Other technologies } \\
\text { Environmental } \\
\text { aspects/waste } \\
\text { handling and } \\
\text { minimization }\end{array}$ & $\begin{array}{l}\text { Pumps } \\
\text { Boilers } \\
\text { - ash transport chutes } \\
\text { - pipes }\end{array}$ & $\begin{array}{l}\text { Improved materials for cavitation } \\
\text { resistance in pumps and improved } \\
\text { abrasion resistance in ash transport } \\
\text { chutes and pipes }\end{array}$ \\
\hline
\end{tabular}




\section{CORROSION}

Corrosion is an inherent problem both in the processing of wood fiber to make pulp and in the processing of pulp to make paper and related products. Although years of corrosion studies and alloy development underpin the present papermaking processes, corrosion remains the most visible and costly materials consideration in the design and operation of these processes. It is therefore relevant to review corrosion concerns based on contacts with representatives of the industry, to prioritize these concerns in terms of energy and economic considerations, and to examine the areas of corrosion expertise within Department of Energy (DOE) facilities that have potential applicability to pulp and paper requirements. This review is intended as a first step in identifying R\&D needs and opportunities that will improve the corrosion performance of materials for pulp and paper production. Shown in Table 2 are specific process areas, components, and materials opportunities where corrosion is important.

Table 2. Corrosion - needs and opportunities

\begin{tabular}{|c|c|c|}
\hline Unit operation & Corrosion site/s & Opportunities \\
\hline Wood preparation & & \\
\hline $\begin{array}{l}\text { Pulp preparation } \\
\text { (mechanical) }\end{array}$ & $\begin{array}{l}\text { Digester } \\
\text { - vessel walls } \\
\text { - pipes } \\
\text { - pumps } \\
\text { - Blow plate } \\
\text { - Tube and shell heat } \\
\text { exchangers }\end{array}$ & $\begin{array}{l}\text { Materials suitable for higher rotation } \\
\text { rates with lower mass and increased } \\
\text { resistance to sulfuric acid corrosion } \\
\text { and chloride pitting in the presence } \\
\text { of steam } \\
\text { Modeling of corrosion processes in } \\
\text { digester to minimize corrosion } \\
\text { through design considerations } \\
\text { Liner materials and/or weld overlays } \\
\text { with improved corrosion resistance } \\
\text { to caustic corrosion and caustic } \\
\text { stress corrosion cracking } \\
\text { More economical blow target plate } \\
\text { materials which will resist } \\
\text { corrosion/erosion by pulp-containing } \\
\text { liquors } \\
\text { Stainless steel heat exchanger tubes } \\
\text { with improved resistance to caustic } \\
\text { and chloride cracking (and acids } \\
\text { used for cleaning) } \\
\text { On-line corrosion monitoring and } \\
\text { diagnostic techniques }\end{array}$ \\
\hline
\end{tabular}


Table 2. (Continued)

\begin{tabular}{|c|c|c|}
\hline Unit operation & Corrosion site/s & Opportunities \\
\hline $\begin{array}{l}\text { Pulp preparation } \\
\text { (continued) } \\
\text { Chemical (continued) }\end{array}$ & $\begin{array}{l}\text { Recovery boiler } \\
\text { - water wall tubes and } \\
\text { studs in furnace } \\
\text { Hearth zone } \\
\text { - primary air ports } \\
\text { - superheater tubes } \\
\text { - smelt spout } \\
\text { - floor } \\
\text { Recovery gasifier (new) } \\
\text { - water wall tubes } \\
\text { - ceramic liner } \\
\text { - gas turbine }\end{array}$ & $\begin{array}{l}\text { Boiler tube materials and surface } \\
\text { coatings with improved resistance to } \\
\text { hydrogen sulfide and stress-assisted } \\
\text { waterside corrosion } \\
\text { Oxidation/sulfidation-resistant } \\
\text { superheater tube materials and } \\
\text { surface coatings suitable for service } \\
\text { at higher steam temperatures } \\
\text { Studies of external stress-assisted } \\
\text { corrosion mechanisms of boiler } \\
\text { tubes in the furnace hearth and } \\
\text { floor } \\
\text { Corrosion-resistant ceramics for. } \\
\text { uncooled water-free smelt spouts } \\
\text { Assess corrosion processes in } \\
\text { gasifiers being developed for } \\
\text { recovery of black liquor chemicals } \\
\text { Ceramics and alloy resistant to hot } \\
\text { surface containing gasifier gases }\end{array}$ \\
\hline Bleaching & $\begin{array}{l}\text { Washer } \\
\text { - deck } \\
\text { - drum } \\
\text { - evaporation/ } \\
\text { condensation sites }\end{array}$ & $\begin{array}{l}\text { Determination of corrosion } \\
\text { mechanism of titanium in alkaline } \\
\text { peroxide solutions } \\
\text { Selection of optimized alloy systems } \\
\text { for } \mathrm{ClO}_{2} \text { bleaching environments } \\
\text { Development of more corrosion- } \\
\text { resistant weld filler materials and } \\
\text { welding practices for aggressive } \\
\text { bleaching environments (currently } \\
\text { there are issues with } \mathrm{ClO}_{2} \text { and } \\
\text { these may increase with superoxides) }\end{array}$ \\
\hline
\end{tabular}


Table 2. (Continued)

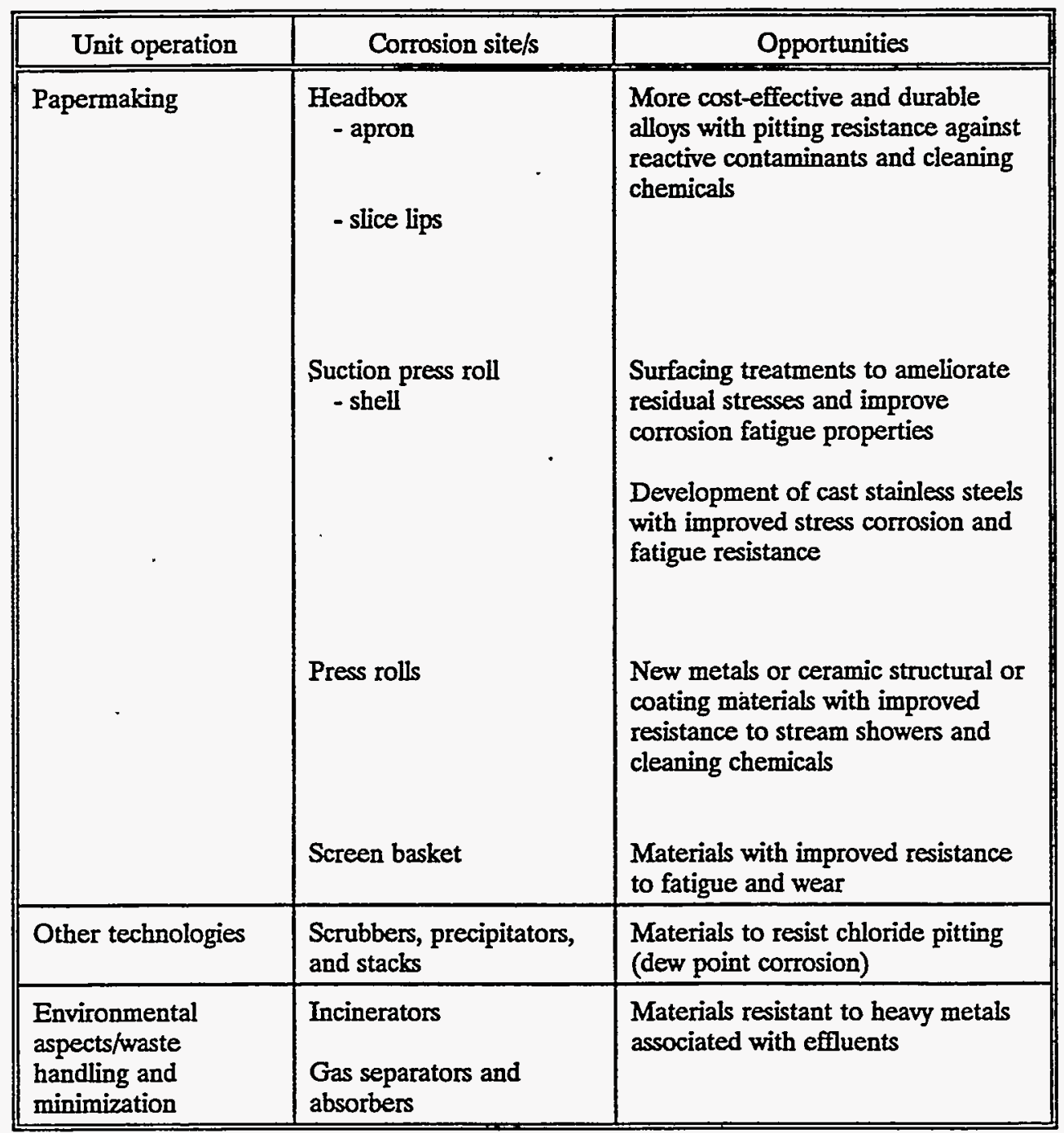




\section{STRUCTURAL AND OTHER ASPECTS}

Structural components (chutes, rolls, vessels, and pipes) and other items such as motors, generators, turbines, and sensors are important to pulp and paper facilities since they affect all unit operations. Cogeneration of electrical power at pulp and paper mills, for example, accounts for nearly $58 \%$ of all the electricity utilized by the industry. Electric motors are used throughout plants. The power level of motors can range from less than 1 to over 30,000 hp. Advances in these areas can improve energy efficiency and reduce downtime. Structural components are also present throughout pulp and paper facilities. Issues in these areas are not directly wear or corrosion controlled. Life prediction methodology is very important to long-term operation. Activities including identifying mechanisms, determining appropriate models, developing data bases, and conducting confirmatory tests are all necessary in order to improve structural components. This review is intended as a first step in identifying research and development needs and opportunities that will improve the performance and integrity of structural and other components for pulp and paper production. Shown in Table 3 are specific process areas, components, and materials opportunities related to these areas.

Table 3. Structural and other aspects - needs and opportunities

\begin{tabular}{|c|c|c|}
\hline Unit operation & Location & Opportunities \\
\hline Wood preparation & & \\
\hline $\begin{array}{l}\text { Pulp preparation } \\
\text { (mechanical) }\end{array}$ & 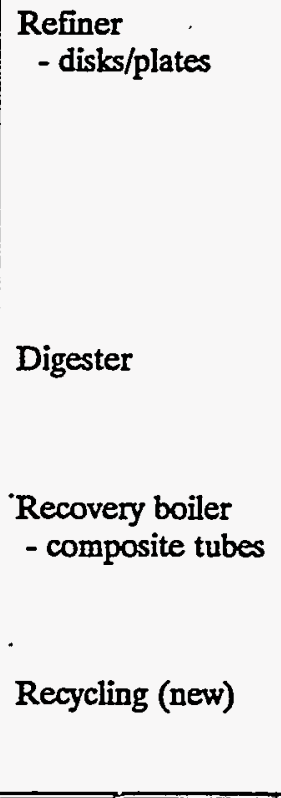 & $\begin{array}{l}\text { Refiner materials suitable for higher } \\
\text { rotation rates with lower mass and } \\
\text { higher fracture toughness and high- } \\
\text { speed bearings } \\
\text { Life prediction modeling including } \\
\text { stress, strain, fracture, hydrodynamic } \\
\text { effects, and vibration analyses } \\
\text { Modeling of digester to identify } \\
\text { areas where significant corrosion } \\
\text { could occur } \\
\text { Nondestructive evaluation technique } \\
\text { to monitor cracks and integrity of } \\
\text { tubes and weldments } \\
\text { Membranes to improve quality and } \\
\text { Btu content of gases from black } \\
\text { liquor gasification processes }\end{array}$ \\
\hline Bleaching & $\begin{array}{l}\text { Washing } \\
\text { Vessels } \\
\text { Piping } \\
\text { Valves }\end{array}$ & $\begin{array}{l}\text { Cleanable filters and membranes to } \\
\text { separate undesired components from } \\
\text { bleaching effluents } \\
\text { Polymer-base structural materials } \\
\text { and coatings } \\
\text { Joining and long-term structural } \\
\text { integrity of materials } \\
\text { Ceramic coatings }\end{array}$ \\
\hline
\end{tabular}


Table 3. (Continued)

\begin{tabular}{|c|c|c|}
\hline Unit operation & Location & Opportunities \\
\hline Papermaking & $\begin{array}{l}\text { Suction press roll } \\
\text { Dryer rolls } \\
\text { Impulse dryer roll } \\
\text { Paper coaters }\end{array}$ & $\begin{array}{l}\text { Structural analyses and design } \\
\text { modifications to reduce cyclic loads } \\
\text { Improved manufacturing processes } \\
\text { including casting, joining, and } \\
\text { machining } \\
\text { Life prediction modeling } \\
\text { More ductile replacement for cast- } \\
\text { iron rolls } \\
\text { Higher modulus (stiffness) to } \\
\text { remove necessity of hydrostatic } \\
\text { element within roll } \\
\text { Improved ceramic coatings on rolls } \\
\text { Develop clay solutions and roll } \\
\text { materials with improved sticking and } \\
\text { releasing characteristics and model } \\
\text { coating process }\end{array}$ \\
\hline Other technologies & $\begin{array}{l}\text { Motors } \\
\text { Motors/generators } \\
\text { Pulp preparation } \\
\text { - recovery boiler }\end{array}$ & $\begin{array}{l}\text { Materials resulting in more efficient } \\
\text { motors and motor controller } \\
\text { Motor current analyses to predict } \\
\text { motor/generator/bearing failures } \\
\text { Robotic inspection techniques to } \\
\text { verify boiler tube integrity } \\
\text { On-line sensors and control to } \\
\text { monitor and control the web and } \\
\text { paper } \\
\text { Sensors and controls to measure } \\
\text { web and paper properties including } \\
\text { stiffness } \\
\text { Improved materials needed which } \\
\text { permit communication with sensors } \\
\text { placed on rotating rolls } \\
\text { Determine fiber properties including } \\
\text { length and orientation on-line }\end{array}$ \\
\hline $\begin{array}{l}\text { Environmental } \\
\text { control/waster } \\
\text { handling and } \\
\text { minimization }\end{array}$ & $\begin{array}{l}\text { Digester } \\
\text { Waste processing }\end{array}$ & $\begin{array}{l}\text { Filters and membranes to reduce } \\
\text { waste stream and minimize } \\
\text { evaporative processes } \\
\text { Membrane materials for separating } \\
\text { volatile compounds and for } \\
\text { removing undesired constituents of } \\
\text { liquid waste streams }\end{array}$ \\
\hline
\end{tabular}




\section{ACKNOWLEDGMENTS}

Special thanks is due to all participants in the meetings and workshops held with respect to the preparation of this report. Summaries of these meetings are listed in the Appendix.

The author also thanks P. J. Wenzel for compiling the Appendix, D. L. Balltrip for preparing the report, $\mathrm{K}$. Spence for editing the report, and G. R. Carter for performing the quality assurance review. 


\section{APPENDIX}

During the past 12 years, the U.S. Department of Energy has, together with industry support, provided funding for the development of technologies that could have a significant impact on the energy efficiency, productivity, and environmental compliance of paper and paperboard manufacture. The paper industry has played an important role in the guidance of this research and development program. An exciting new task is being undertaken to develop a more comprehensive and formalized strategic plan for DOE's paper program.

Information from meetings and workshops held with representatives of the pulp and paper industry, materials and equipment manufacturers, universities and institutes, U.S. DOE, and DOE national laboratories, as well as some textbooks, was used in the development of this program and to gather information in support of this report. A listing of these meetings and workshops follow:

- Opportunities and Needs for Materials in the Pulp and Paper Industry visit by personnel from the Institute of Paper Science and Technology, November 1992, Oak Ridge, Tennessee

- Opportunities and Needs for Materials in the Pulp and Paper Industry, December 10, 1992, Oak Ridge, Tennessee

- Bowater Pulp and Paper Plant, December 1992, Calhoun, Tennessee

- Institute of Paper Science and Technology, December 1992, Atlanta, Georgia

- Pulp and Paper Mill of the Future Workshop, February 3-5, 1993, Reston, Virginia

- Joint AFPA-BLRBAC Maintenance Seminar, April 7-8, 1993, Atlanta, Georgia

- Government/Industry Pulp and Paper Workshop, August 12-13, 1993, Portland, Oregon

- Pulp and Paper Mill of the Future - An Information Exchange, September 8-10, 1993, University of Maine, Orono 
MEETING TITLE: Opportunities and Needs for Materials in the Pulp and Paper Industry Visit by personnel of the Institute of Paper Science Technology

SPONSOR: Advanced Industrial Materials (AIM) Program

LOCATION: Oak Ridge National Laboratory, Oak Ridge, Tennessee

DATE: November 1992

The objective of this meeting was for the Institute of Paper Science Technology (IPST) personnel to identify critical materials issues related to the pulp and paper industry. The information was used to develop a preliminary needs assessment and to help define future planning meetings for the Materials Needs Assessment. Attendees included staff from ORNL, IPST, and DOE program managers. 
MEETING TITLE: Opportunities and Needs for Materials in the Pulp and Paper Industry SPONSOR: Advanced Industrial Materials (AIM) Program

LOCATION: Oak Ridge National Laboratory, Oak Ridge, Tennessee

DATE: December 1992

The goal of this meeting was to identify new applications of materials for pulp and paper processing. Information will be used to develop a program plan for the Office of Industrial Technologies, Advanced Industrial Materials (AMM) Program. An agenda and list of attendees follows. 


\section{AGENDA}

"Opportunities and Needs for Materials in the Pulp and Paper Industry"

\section{Advanced Industrial Materials (AIM) Program \\ Oak Ridge National Laboratory (ORNL) \\ Building 6008}

Hosted By: Peter Angelini

Thursday, December 10, 1992

Time

$8: 30$

$8: 40$

8:55

$9: 40$

10:10

$10: 25$

$12: 00$

1:00

$2: 30$
Topic

Weicome

Introduction and Meeting Goals

Pulp and Paper Industry Programs

Background on ORNL

Break

Industrial Perspective

- Aridritz Sprout Bauer

- Bowater

- Champion International

- Georgia-Pacific

- Thermo-Chem

- Westvaco Corporation

- Weyerhaeuser Paper Company

- University of Wisconsin-Platteville

- Institute of Paper Science \& Tech.

Lunch (Catered)

Continue Industrial Perspective

Session

Discussion session on materials needs including: Corrosion/Metallic Coatings; Wear; Heat Transfer/ Insulation; Structural Materials (welding, fatigue, stress); Ceramics/Coatings; Chemical Processing; Environmental; Nondestructive Evaluation (sensing/controls); and other areas of particular interest.

\section{Person}

Peter Angelini ORNL

Charlie A. Sorrell DOE-AIC Materials Program

Stan F. Sobczynski DOE-Pulp and Paper Program

Anthony C. Schaffhauser ORNL
William L. Bohn
John Griffey
LeRoy Hershey
David C. Bennett
Kari T. Morency
K. Durai-Swamy
William Steedman
W. B. A "Sandy" Sharp
Peter Gorog
Ronald A. Yeske
Jeff Colwell
Maclin Hall
David Orloff

\author{
All \\ (Jack DeVan, Jim Keiser, \\ Charles Yust, Tom Kollie, \\ Tom Zacharia, Gus Aramayo, \\ Chuck Brinkman, Bob Lauf: \\ Doug Fain, Charlie Byers, \\ Steve Hildebrand, Dan \\ McGuire, Dan McDonald)
}




\section{AGENDA}

"Opportunities and Needs for Materials in the Pulp and Paper Industry"

$$
\begin{gathered}
\text { Advanced Industrial Materials (AIM) Program } \\
\text { Oak Ridge National Laboratory (ORNL) } \\
\text { Building } 6008
\end{gathered}
$$

Hosted By: Peter Angelini

Friday, December 11, 1992

Time
Topic

Continuation of Discussion Session on Materials Needs (if not completed the previous day) followed by Discussion and Report on Selected Topics

Break

Continuation of Discussions

Lunch (Catered)

Summary session

All

$\underline{\text { Person }}$

All

Adjourn

Tours of Facilities available 


\section{OPPORTUNITIES AND NEEDS FOR MATERIALS IN THE PULP AND PAPER INDUSTRY}

December 10, 1992

\section{ATTENDEES LIST}

Moonis Ally, Oak Ridge National Laboratory Peter Angelini, Oak Ridge National Laboratory Chuck R. Brinkman, Oak Ridge National Laboratory Charles H. Byers, Oak Ridge National Laboratory Jefferey A. Colwell, Institute of Paper Science \& Technology, Inc.

John V. Coyner, Oak Ridge National Laboratory Janet H. Cushman, Oak Ridge National Laboratory David Dawson, Oak Ridge National Laboratory Jack H. DeVan, Oak Ridge National Laboratory Doug E. Fain, K-25

Elmer Fleischman, EG\&G Idaho, Inc., INEL John E. Griffey, Bowater, Inc.

Maclin S. Hall, Institute of Paper Science \& Technology, Inc. LeRoy Hershey, Bowater, Inc.

Eugene E. Hoffman, Department of Energy/Oak Ridge James R. Keiser, Oak Ridge National Laboratory Robert J. Lauf, Oak Ridge National Laboratory Dan W. McDonald, Oak Ridge National Laboratory Karl T. Morency, Georgia-Pacific Corp. Ronald L. Musselman, Andritz Sprout Bauer Mitch Olszewski, Oak Ridge National Laboratory Dave Orloff, Institute of Paper Science \& Technology, Inc. Arvid E. Pasto, Oak Ridge National Laboratory David A Scearce, Thermo-Chem, Inc. Anthony S. Schaffhauser, Oak Ridge National Laboratory W.B.A. "Sandy" Sharp, Westvaco Corp. Philip S. Sklad, Oak Ridge National Laboratory Stanley F. Sobczynski, Department of Energy/HQ Charles A. Sorrell, Department of Energy/HQ Joan K. Young, Battelle Pacific Northwest Laboratories Charles S. Yust, Oak Ridge National Laboratory Thomas Zacharia, Oak Ridge National Laboratory 
MEETING TITLE: Bowater Pulp and Paper Plant

SPONSOR: Advanced Industrial Materials (AlM) Program

LOCATION: Calhoun, Tennessee

DATE: December 1992

The purpose of this meeting was to tour the Bowater Pulp and Paper Plant in order to gain familiarity with the papermaking process. 
MEETING TITLE: Institute of Paper Science and Technology

SPONSOR: Advanced Industrial Materials (AIM) Program

LOCATION: Atlanta, Georgia

DATE: December 1992

The purpose of this meeting was to tour the Institute of Paper Science and Technology Research facilities to become familiar with capabilities. 
MEETING TITLE: Pulp \& Paper Mill of the Future Workshop

SPONSOR: U. S. Department of Energy, Office of Industrial Technologies

LOCATION: Hyatt Regency, Reston, Virginia

DATE: February 3-5, 1993

The purpose of this meeting was to gather information used to assist in the development of the Office of Industrial Technologies (OIT) Paper Mill of the Future Program Plan and acquaint attendees with the on-going program being conducted in pulp and paper R\&D. This information will be used to strengthen the current Pulp and Paper R\&D Program. The objectives of the workshop were to obtain meaningful input to the OIT Pulp and Paper Program Plan, to inform the paper industry of the development of this plan, to present the mission of the Office of Industrial Technologies to the paper industry, to provide the opportunity for industry, universities, and national laboratories to share technology needs and capabilities, and to provide a mechanism for a continuing dialogue with the paper industry. Attendees included personnel from the paper industry, its suppliers, universities, private R\&D institutes, the DOE, and national laboratories. A draft of this report "Materials Needs and Opportunities in the Pulp and Paper Industry" was distributed for comments and review at the meeting. An agenda and list of attendees follows. 


\section{Pulp \& Paper Mill of the future Workshop}

Sponsor. U.S. Dapartment \& Energy, Office of Industial Technologies

Location: Hyatt Regency Reston, (703)-709-1231, FAX (703)-709-2281

Fobruary 3-5, 1993

\section{Revised Agenda}

\section{WEDNESDAY, FEBRUARY 3, 1993}

10:00 am

Registration

(Note: Lunch not provided)

\section{The Paper Industry Vision of the Future}
$.1: 00 \mathrm{pm}$
Welcome to Paricipams
S. Sobczynski, U.S. Department of Energy
1:15 pm
The Federal Role Today in Technology Development
A. Streb, U.S. Department of Energy
$2: 00 \mathrm{pm}$
The Paper Industry Today and ts Needs of the Future
Speaker: Dr. D. Raymond, Weyerhaeuser Paper Company
$2: 45 \mathrm{pm}$
Workshop Objectives
D. Wiley, U.S. Deparment of Energy
$3: 00 \mathrm{pm}$
Breakout Group Assignments
S. Sobczynski, U.S. Department of Energy
$3: 15 \mathrm{pm}$
Breakout Sessions f(Groups A, B, C, D):
Each group will address The Vision for the Paper Mill of the Future
$5: 00 \mathrm{pm}$
FEEDBACK PRESENTATIONS
Vision for Paper Mill of the Future (Groups A, B, C, D)
$6: 30 \mathrm{pm}$
Adjoum
$7: 00 \mathrm{pm} \cdot 8: 30 \mathrm{pm}$
Reception - hors d'courve and cash bar
(Dinner on your own) 
(Agenda, Page 2 of 3)

Thursoay, February 4, 1993

7:00 am - 8:00 am

8:00 am

8:15 am

10:30 am

$10: 45 \mathrm{am}$

$12: 00 \mathrm{pm}$

$2: 00 \mathrm{pm}$

2:15 pm

5:30 pm

$6: 30 \mathrm{pm}$

7:00 pm
Continental Breakfast

\section{Industry Drivers}

Breakout Group Assignments

S. Sobczynski, U.S. Department of Energy'

Group E - Energy Supply

Group $F$. Process Efficiency

Group G - Waste Reduction

Break

FEEDBACK PRESENTATIONS

Vision for Industry Drivers (Groups E, F, G)

Lunch

Thisd Generation R\&D

Speaker: W. E. 'Par Clarke, Arthur D. Little, Inc.

\section{Vision for Pulp and Paper Technologies}

Breakout Assignments

S. Sobczynski, U.S. Department of Energy

Breakout Sessions

Group H: Pulping, TMP, CTMP

Group J: Bleaching

Group K: Chemical Recovery

Group L: Papermaking, Other

Adjourn

Cash Bar

Dinner

Competitive Factors in the international Pulp and Paper Industry Speaker: Dr. R. Slinn, AFPA 
(Agenda, Page 3 of 3)

Friday, February 5, 1993

7:00 am - 8:00 am

8:00 am

8:15 am

$10: 30$ am

$10: 45$ am

$11: 30 \mathrm{am}$
Continental Breakfast

Announcements/Workshop Assignments

\section{FEEDACK PRESENTATIONS}

Vision for Pulp and Paper Technologies (Groups $H, J, K, L$ )

Wrap up

S. Sobczynski, U.S. Dopartment of Energy

Closing Remarks

D. Swink, U.S. Department of Energy

Adjourn - Lunch

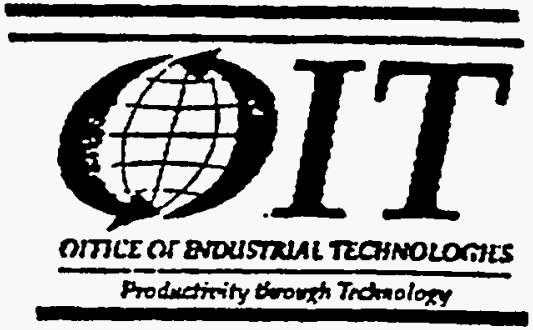


PULP AND PAPER MIL OF THE FUTURE WORKSHOP

February 3-5, 1993

\section{ATTENDEES LIST}

Cyrus Aidun, Institute of Paper Science \& Technology, Inc.

Robert Allen, Department of Energy/Boston

James Anderson, Herty Foundation Development

R. Anderson, Oak Ridge National Laboratory

Peter Angelini, Oak Ridge National Laboratory

Peter Ariessohn, Weyerhaeuser Paper Company

A. D. Armstrong, Georgia-Pacific Corp.

Karl Ayers, The Mead Corp.

Sujuit Banerjee, Institute of Paper Science \& Technology, Inc.

Robert Bareiss, Bareiss Associates

Richard Barker, Union Camp Corp.

Joe Barsin, Goraveiken

Paul Bayer, Energetics, Inc.

Alexander Bonsu, International Paper

David Boron, Department of Energy, Office of Industrial Technologies

Joseph Bozell, National Renewable Energy Laboratory

Taz Bramlette, Sandia National Laboratories

L. Busker, Beloit Corp.

Charles Byers, Oak Ridge National Laboratory

Robert Chappell, Department of Energy/Golden

Helena Chum, National Renewable Energy Laboratory

W. E. Clarke, Arthur D. Little

John Clement, The Babcock and Wilcox Company

Jeffrey A. Colwell, Institute of Paper Science \& Technology, Inc.

Charles Covino, General Magnaplate Corp.

Bruce Cranford, Department of Energy, Office of Industrial Waste Reduction

Oscar Crisalle, University of Florida

Harold Davis, Monadnock Process Engineering

Jack DeVan, Oak Ridge National Laboratory

Richard Diehl, Textron Defense Systems

Donald Dimmel, Institute of Paper Science \& Technology, Inc.

Darryl Dodson-Edgars, Boise Cascade Corp.

Patricia J. Dollar, Corporation on Resource Recovery and the Environment

Elisabeth M. Drake, Massachusetts Institute of Technology

K. Durai-Swamy, MTCI/ThermoChem

Richard Ellis, Institute of Paper Science \& Technology, Inc. Jeff Empie, Institute of Paper Science and Technology, Inc.

Ronald Estridge, James River Corp.

Douglas E. Fain, Sr., Oak Ridge National Laboratory

John Fildes, BIRL/Industrial Research Laboratory

Jack Firkins, Institute of Paper Science \& Technology, Inc.

Elmer Fleischman, Idaho National Engineering Laboratory

W. Frederick, Oregon State University 


\section{PULP AND PAPER MIIL OF THE FUTURE WORKSHOP}

February 3-5, 1993

ATTENDEES LIST

(continued)

Arthur Fricke, University of Florida

Simon Friedrich, Department of Energy, Office of Industrial Technologies

Joseph Genco, University of Maine

Gary Gettmann, Georgia-Pacific Corp.

Bob Giese, Giese and Associates

Don Gilmore, TAPPI

Peter Gorog, Weyerhaeuser Paper Company

Thomas Grace, T. M. Grace Company, Inc.

William Griffith, Oak Ridge National Laboratory

Maclin Hall, Institute of Paper Science \& Technology, Inc.

Marquita Hill, University of Maine

Harold Hintz, Westvaco Corp.

Patricia Hoffman, Energetics, Inc.

Robert H. Horton, Institute of Paper Science \& Technology, Inc.

Jeffrey Hsieh, Georgia Institute of Technology

Ehr Ping HuangFu, Department of Energy, Office of Industrial Technologies

Peter J. Ince, Department of Agriculture Forest Service

Robert Jacobs, ABB Combustion Engineering

Keith Johnson, Scott Paper Company

Richard Johnson, BIRL/Industrial Research Laboratory

Todd Johnson, Babcock and Wilcox

Jay Keller, Sandia National Laboratories

Michael Kelley, Advanced Refractory Technologies

Robert Kinstrey, RUST Engineering

Michael Kocurek, Herty Foundation Development

John Koning, Department of Energy Forest Products Laboratory

David Kraske

Gopal Krishnagopalan, Auburn University

Veli Lapinoja, Georgia-Pacific Corp.

Perry Lindstrom, National Critical Materials Council

Earl W. Malcolm, Institute of Paper Science \& Technology, Inc.

Amal Mansour, MTCI

Momtaz Mansour, MTCI

R. C. Massey

Thomas McDonough, Institute of Paper Science \& Technology, Inc.

Ronald McHugh, Department of Energy

Robert Mcllroy, Babcock and Wilcox

Jim Mills, Idaho National Engineering Laboratory

Phill Mitchell, KAMYR

Algis Mockaitis, Stone Container Corp.

Richard Murphy, Oak Ridge National Laboratory

Jon Myers, P. H. Glatfelter Company 
PULP AND PAPER MILL OF THE FUTURE WORKSHOP

February 3-5, 1993

ATTENDEES LIST

(continued)

James Neff, BETZ

Ogbemi Omatete, Oak Ridge National Laboratory

Gregory Ondich, Department of Energy, Environmental Protection Agency

David Orloff, Institute of Paper Science \& Technology, Inc.

Ralph Overend, National Renewable Energy Laboratory

Michael Pearce, General Magnaplate

Frank H. Pichette, Scott Paper Company

John Pinkerton, NCASI

Shalendra Porwal, Battelle Pacific Northwest Laboratories

John Racine, Stone and Webster

Arthur J. Ragauskas, Institute of Paper Science \& Technology, Inc.

Ram Ramarao, Empire State Paper Research Institute

G. Julian Reid, TAPPI

David Rolfe, S. D. Warren Company

Niel Rossmeissl, Department of Energy, Office of Industrial Technologies

Alan W. Rudie, Institute of Paper Science \& Technology, Inc.

H. Rumph, Orion CEM, Inc.

Francis Ruppel, Oak Ridge National Laboratory

James Rushton, O’Neal Engineering, Inc.

Rolf Ryham, Ahlstrom Recovery, Inc.

Henry Said, ThermoChem, Inc.

Peter Salmon-Cox, Department of Energy, Office of Industrial Technologies

Robert Salter, Osmotek, Inc.

Dale Schaefer, Sandia National Laboratories

A. C. Schaffhauser, Oak Ridge National Laboratory

Linda Schilling, Department of Energy, Office of Industrial Technologies

Martin Schroeter, Herty Foundation Development

William Scott, Miami University

Barry Seidel, BE\&K

Peter Seifert, Black Clawson Company

W.B.A. Sharp, Westvaco Corp.

Thomas Single, James River Corp.

Philip S. Sklad, Oak Ridge National Laboratory

John M. Smuk, Potlatch Corp.

Lucinda B. Sonnenberg, Institute of Paper Science \& Technology, Inc.

Charles A. Sorrell, Department of Energy, Office of Industrial Technologies

Louis Sousa, Bureau of Mines

Richard Steiger, Stone and Webster Engineering Company

Frank Stodolsky, Argonne National Laboratory

David Streit, Proctor and Gamble Cellulose

Paul Stuart, BEAK Consultants, Ltd.

Samuel Suh, Champion International 


\section{PULP AND PAPER MILL OF THE FUTURE WORKSHOP}

February 3-5, 1993

ATTENDEES LIST

(continued)

Raymond Taylor, Georgia-Pacific Corp.

William Thompson, Bailey Controls Company

Matthew Van Hook, AFPA

Allan Walsh, J. H. Jansen Company

Theodore Wegner, Department of Agriculture, Forest Services, Forest Products Laboratory

Henry Wells, University of Minnesota

Torsten Wesslen, Foxboro

William Wilkinson, Stone Container Corp.

James R. Whetstone, National Institute of Standards and Technology

Bernard Yaros, Scott Paper Company

Joan Young, Battelle Pacific Northwest Laboratory

Charles S. Yust, Oak Ridge National Laboratory

Erdan Yuzak, Champion International 
MEETING TITLE: Joint AFPA-BLRBAC Maintenance Seminar

(American Forest Products Association and

Black Liquor Recovery Boiler Advisory Committee)

SPONSOR: Advanced Industrial Materials (AIM) Program

LOCATION: Sheraton Airport Hotel, Atlanta, Georgia

DATE: April 7-8, 1993

The topics of the seminar were inspection methods, procedures, and results. Information was presented that allowed knowledge to be gained relative to problems (corrosion, scc, etc) in black liquor recovery boilers, how the inspection programs were geared to control the problems and what non-destructive examination approaches were being used to periodically evaluate the boiler components. An agenda for this meeting follows but no attendance list was provided from the seminar. 


\section{JOINT AFPA - BLRBAC MAINTENANCE SEMINAR \\ APRIL 7, 1993, 10 AM - 5 PM \\ APRIL $8,1993,8$ AM - NOON \\ SHERATON ATLANTA AIRPORT HOTEL \\ 1325 VIRGINIA AVENUE, ATLANTA, GEORGIA}

\section{SESSION I Fundamentals of a Planned Inspection Program}

Key elements and the application of an organized planning process to optimize a maintenance inspection

- Elements of a Successful Inspection Program

- Jim Jordan, ABB C-E

- Possible Discussion (No paper)

- To be announced

- Preparation for Repair - A Contractor's Perspective

- Ron Blodgett, ABB C-E

- The Inspection and the National Board Inspection Code (NBIC)

- Barry Bobo, Hartford Steam Boiler Inspection and Insurance Company

- Panel Discussion

SESSION II Visual Inspection Techniques

Modern Visual Inspection Techniques to Assure Reliability and Detect Problems on a Timely Basis

- Application of Inspection Knowledge, Equipment and Techniques

- Carl Lohstroh, Weyerhaeuser

- Modern Visual Inspection Techniques

Recovery Boilers

- Gunnar Thorslund, Tampella

- Panel Discussion

SESSION III NDT/DT Inspection Techniques

Managing a NDT/DT Program to Assure Where to Inspect, How to Assure the Quality of Inspection Training and Certification

- (Tentative) Training and Certification to Accepted Standards

- Jacques Brignac, ABB C-E

- Non-Destructive Examination (NDE)

- Ralph Murphy, Babcock \& Wilcox

- The Use of Non-Destructive Testing in a Recovery Boiler

- Jim Treat, Longview Fibre hispzclion

- Corrosion Inspection of Recovery Boilers

- W. B. A. Sandy Sharp, Westvaco Corp

- Panel Discussions 
JOINT AFPA - BLRBAC MAINTENANCE SEMINAR

APRI 7, 1993 10:00 AM - 5:00 PM

APRL 8, 1993 8:00 AM - 12:00 NOON

- Page 2 -

SESSION IV SPECIAL INSPECTION TECHNIQUES

- Understanding the Special Mechanisms of near Drum Corrosion and Stress Assisted Cracking/Corrosion and the Techniques for Inspection

- Near Drum Corrosion, the Problem

- Doug Singbill, PAPPRICAN

- How to Inspect for "NDC"

- Charles Guzi, Lamda Technology USA

- Stress Assisted Corrosion, the Problem

- Joan Barna, Babcock \& Wilcox

- X-Ray Inspection Techniques for Stress Assisted Corrosion

- Lloyd Sutton, INDT

- Panel Discussion

SESSION V Evaluation of Inspection Data and Long Term Planning

- How can the Inspection Results be Evaluated to Develop Proactive Maintenance Program

- Computer Analysis and Trending

- Tom Ridgeway, TCRI

- Mill Perspective on Inspection Evaluation and Maintenance Planning

- Jim West, Weyerhaeuser

- Inspection Data Managed for Enhanced Predictive Maintenance

- Tom Enright, $-\mathrm{ABB} C-\mathrm{E}$

- Panel Discussion 
MEETING TITLE: Government/Industry Pulp and Paper Workshop

SPONSOR: Office of Industrial Technologies and Advanced Industrial Materials (AIM) Program

LOCATION: Portland, Oregon

DATE: August 12-13, 1993

The purpose of this effort was to identify further needs and opportunities for improved materials and process equipment of the pulp and paper industry. This information will be used by the Office of Industrial Technology and the Advanced Industrial Concept Division of DOE to plan new initiatives to support Paper Mill 2020. This workshop is being held to identify the most serious problems that occur during pulp and paper processing resulting from the use of suboptimal materials and process equipment. The goal of the workshop was to obtain an in-depth identification of needs and specific recommendations for joint laboratory/industry research projects. Attendees included representatives from large integrated northwest pulp and paper mills, paper industry machinery manufacturers, regional academic institutions and technical associations for the pulp and paper industry. Laboratory staff knowledgeable of both materials issues and pulp and paper technology were invited. An agenda and list of attendees follows. 


\section{WORKSHOP AGENDA}

Government/Industry Workshop on

Opportuniries for New Materiais and Processes

in Pulp and Paper Processing

August 12, 1993

TOURS - Non-paper industry participants - General mill tours are intended for workshop participants who wish to be introduced to and gain familiarity with pulp and paper process methods. Northwest paper mill participants should attend in the afternoon.

Location: Portland Downtown Holidav Inn

7:00 a.m. LEAVE FROM DOWNTOWN PORTLAND HOLIDAY INN LOBBY FOR LONGVIEW, WA - Prior reservation oniy, meet at Portiand Downtown Holiday Inn Lobby at 7:00 a.m., or drive on your own.

Location: Longview, WA -- see map

8:30 a.m. - TOUR OF LONGVIEH FIBRE 11:00 p.m.

11:15 - TOUR OF NORTH PACIFIC PAPER (NORPAC)

12:30 p.m.

1:00 - * RETURN RIDE/BOX LUNCH

2:00 p.m.

WORKSHOP SESSION BEGINS - All

Location: 3rd Floor 500 NE Multnomah Lacross from Lloyd Center and Portland Downtown Holidav (nn)

2:00 p.m. INTRODUCTIONS/AGENDA

(Joan K. Young. Pacific Northwest Laboratory)

2:15- $\quad$ REVIEW OF PAPER MILL 2020 INITIATIVE

2:45 p.m. (Stan Sobczynski, U.S. Deparment of Energy)

2:45 - WELCOME/Advanced Industrial Materials Program Objectives

3:00 p.m. (Charles A. Sorrell, U.S. Department of Energy)

3:00 - REVIEW OF PREVIOUS AICD EFFORTS - Candidate Materials and Processes

3:45 p.m. (Peter Angelini, Oak Ridge National Laboratory) 
3:45 - GENERAL INDUSTRY PERSPECTIVE - General Trends in Pulp and Paper

4:15 p.m. Production (Richard Haynes, U.S. Forest Service)

4:30 - TOUR OF OLD GROWTH STAND ( $1 \mathrm{hr} . \& 20 \mathrm{~min}$. away, some van space 8:00 p.m. available with prior notice. We will stop for dinner in route.)

August 13. 1993

8:00 a.m. COFFEE/NTRODUCTIONS ${ }^{(2)}$

8:15 - PAPER INDUSTRYISUPPLIERS PERSPECTIVE (contd.) - Corrosion, Wear, and

9:15 a.m. Other Problems in the Pulp and Paper Process Technology (Weyerhaeuser, Boise

Cascade, James River, Simpson, Mead Corporation, others)

9:15 - OPEN DISCUSSION - All paper mill participants have the opportunity to discuss

10:30 a.m. problems and technical concerns.

$10: 30-$

DOE NATIONAL LABORATORY CAPABILITIES

$11: 45$ a.m.

- Battelle Pacific Northwest Laboratory, Energy and Materials Programs (Bill Samuels)

- Oak Ridge National Laboratory, Advanced Industrial Materials Program (Peter Angelini)

- $\quad$ Sandia National Laboratory, Programs (Bob Carling)

- Idaho National Engineering Laboratory, Programs (Bob Neilson)

- Los Alamos National Laboratory, Programs (Gerald Maestas)

- National Renewable Energy Laboratory, Programs (Helena Chum)

- Other

12:00 p.m. LUNCH PRESENTATION - CRADAs and Working with the DOE National Laboratories

1:00 -

DOE NATIONAL LABORATORY CAPABILITIES (contd.)

2:30 p.m.

2:30 -

4:30 p.m.

- Finnish Pulp and Paper Industry (Christina Hagstrom-Nasi, TEKES)

- Pulp and Paper Research at IPST Engineering and Paper Division (David Orloff. Instirute of Paper Science and Technology)

4:30 - DISCUSSION/WRAP-UP

5:00 p.m.

(a) Breaks taken as time permits. 


\section{GOVERNMENT/INDUSTRY PULP AND PAPER WORKSHOP}

August 12-13, 1993

\section{ATTENDEES LIST}

Charles A. Allen, Idaho National Engineering Laboratory

Peter Angelini, Oak Ridge National Laboratory

Helena Chum, National Renewable Energy Laboratory

Darryl Dodson-Edgars, Boise Cascade Corporation

Dennis Forbes, James River Corporation

Bob Giese, Giese \& Associates

Y. P. Fang, Simpson

Jack Goldfrank, Mead Corporation

Margaret Gorog, Weyerhaeuser Company

Peter Gorog, Weyerhaeuser Company

Rick Gustafson, University of Washington

Christine Hatstrom-Nasi, TEKES Technology Development Center

Richard Haynes, PFSL

Arlon Hunt, Lawrence Berkeley Laboratory

Densmore Hunter, Weyerhaeuser Company

James R. Keiser, Oak Ridge National Laboratory

Duane Lindner, Sandia National Laboratory

Gerry Maestas, Los Alamos National Laboratory

Robert J. McTee, Weyerhaeuser Company

Robert M. Neilson, Jr., EG\&G Idaho, Inc.

David Orloff, Institute of Paper Science \& Technology

Wayne Robbins, Institute of Paper Science \& Technology

Thomas P. Roberts, Mead Central Research Laboratories

W. D. Samuels, Battelle Pacific Northwest Láboratory

Stanley F. Sobczynski, U.S. Department of Energy

Charles Sorrell, U.S. Department of Energy

W. W. Vantzelfden, James River Corporation

Carol Wiseman, Boise Cascade Corporation

Ainslie T. Young, Los Alamos National Laboratory

Ray Witter, James River Corporation 
MEETING TITLE: Pulp and Paper Mill of the Future - An Information-Exchange

SPONSOR: Office of Industrial Technologies and Advanced Industrial Materials (AIM) Program

LOCATION: University of Maine, Orono

DATE: September 8-10, 1993

The DOE has historically sponsored research in the pulp and paper industry under the program direction of Stan Sobczynski. DOE recognizes the need to work more closely with U.S. industry in other program areas, including, for example, materials research, recycling, and waste minimization. The National Laboratories are a resource for collaborative research with industry, and there is an increased realization of the need for the Laboratories to perform research that supports U.S. industry. For effective cooperative efforts among interested parties, each needs to understand the needs, interests, and capabilities of the others. At this meeting, industry personnel summarized the research needs of the pulp and paper industry, and colleges and others with pulp and paper technology programs made use of a poster session to present their capabilities to address these needs. The DOE National Laboratories discussed their capabilities and how they might be useful to the pulp and paper industry. An agenda and list of attendees follows. 


\section{Pulp and Paper Mill of the Future -- \\ an information-exchange \\ September $8-10,1993$}

University of Maine, Orono, Department of Chemical Engineering

Sponsored by the

U.S. Department of Energy Office of Industrial Technologies

and the U.S. DOE Laboratories

\section{Wednesday September 8}

8 am-5 pm Introduction to Pulp and Paper Making for newcomers to the industry with

Dr. Joseph Genco, Univ. of Maine, followed by afternoon paper mill visit.

Wednesday Evening - plenary session begins

6-7:30 pm Reception (cash bar) Jenness Hall lobby includes tour of $P \& P$ Pilot Plant.

Dinner on your own.

Thursday September 9

$\underline{8: 30-9 \mathrm{am}}$

Welcome, Judy Bailey, Vice President, Research and Public Service, Univ of Maine Purpose of meeting, Stanley Sabczynski, U.S. DOE

U.S. DOE's Advanced Industrial Concepts Division - what they do and what they need to know about $P \& P$ needs

9-noon Pulp and Paper Mill of the Future - Vision Statement

$P \& P$ industry representative presentations - research needs in raw materials, the environment, pulping and bleaching, paper-making, surface and structural materials, sensors and process control, chemical recovery, recycling, materials \& maintenance.

$\underline{12-1} \quad$ Lunch

$1-5 \mathrm{pm}$

Finish P\&P industry presentations on research needs

R\&D capabilities of colleges and others working to meet industry needs -- an overview presentation followed by a poster session served up with refreshments.

6 pm Dinner at Black Bear Inn

Research funded by DOE's P\&P Processes program, S.Sobczynski, DOE

Major presentation being arranged

Entertainment

Friday September 10

8:30 am - noon Capabilities and interests of the U.S. DOE National Labs -- presentations Discussion and closing

noon

Lunch

For more information, call Marquita Hill, Tel: 207/ 581-2301

or Betty Ingraham, Tel: 207/581-2281 (FAX 207/581-2323). 
PULP \& PAPER MILL OF THE FUTURE--AN INFORMATION EXCHANGE LIST OF SPEAKERS AS OF JULY 30, 1993

Pulp and Paper Industry

Vision statement

Delmar Ravmond, Weyerhaeuser

Phone $\quad \underline{\text { Fax }}$

Raw materials

William Foster

206/ 924-6850

924-6540

Environmental Concerns

Ron Estridge, James River

$517 / 631-0908$

$631-1755$

$804 / 649-4209$

$343-8592$

Pulping/bleaching

Harry Hirte, Westvaco

$212 / 318-5412$

Paper making processes

Dan W. Manson, Manson and Associates 404/ 237-3939

$261-6920$

Surface \& structural materials

Anthony Lyons, Repap Technologies

$215 / 630-9630$

630-0966

Sensors/process control

Gary Baum, James River

$414 / 729-8161$

$729-8161$

Recycling

Tom Friburg, Weyerhaeuser

$2006 / 924-6204$

Chemical Recovery

Tom Grace, T.M. Grace Co.

$414 / 734-4434$

$734-4505$

Materials/maintenance

Sandy Sharp, West Vaco

$301 / 497-1330$

497-1309

National Lab speakers

Oak Ridge

Peter Angelini, lead talk on Sep 10

$615 / 574-4565$

$574-6098$

Los Alamos

Gerald Maestas

$505 / 667-3973$

$667-8873$

Sandia

Dale Schaefer

$505 / 844-7937$

$844-4947$

NREL

Estabon Chornet

$303 / 231-1384$

(Robert Evans, contact person)

Battelle, Pacific Northwest Lab

Douglas Eliott

$509 / 375-2248$

$375-2059$

DOE

Pulp and Paper Processes

Stanley Sobczynski

202/586-1878

$586-8134$

Advanced Industrial Concepts Div.

Charles Sorrell 
September 8-10, 1993

ATTENDEES LIST

Said M. Abubakr, Forest Products Laboratory

Peter Angelini, Oak Ridge National Laboratory

Raja G. Aravamuthan, Western Michigan University

James E. Battles, Argonne National Laboratory

Gary A. Baum, James River Corporation

Roger C. Bavoux, U.S. Department of Energy-Boston

Douglas Bousfield, University of Maine

Mike Boyle, University of Maine

Charles $\mathrm{H}$. Byers, Oak Ridge National Laboratory

Med Byrd, North Carolina State University

Hou-min Chang, North Carolina State University

Jack Chinn, Madison Paper Industries

Esteban Chornet, National Renewable Energy Laboratory

J. L. Clement, The Babock \& Wilcox Company

Barbara Cole, University of Maine

Karl M. Counts, Herty Foundation Development Center

Harry T. Cullinan, Pulp and Paper Research \& Education Center

Al Cyr, Sr., Resource Recovery, Inc.

Robert L. Dalton, Center for Technology Transfer

Joseph E. DeWees, U.S. Department of Energy

Richard C. Diehl, Textron Defense Systems

James R. DiStefano, Oak Ridge National Laboratory

Steven Edwards, Kimberly Clark Corporation

Douglas C. Elliott, Pacific Northwest Laboratory

H. Jeff Empie, Institute of Paper Science \& Technology

Toshibaru Enomae, University of Maine

Ron Estridge, James River Corporation

Douglas E. Fain, Martin Marietta Energy Systems, Inc.

Lad Falat, Westvaco

Ted Farrington, Kimberly Clark Corporation

Elmer Fleischman, Idaho National Engineering Laboratory

William A. Foster

Raymond C. Francis, ESPRI

W. J. Frederick, Oregon State University

Tom Friberg, Weyerhaeuser

Art Fricke, University of Florida

Thomas E. Fritz, Argonne National Laboratory

Joseph M. Genco, University of Maine

Thomas M. Grace, T. M. Grace Company, Inc.

Eric Hass, U.S. Department of Energy

Marquite Hill, University of Maine

Harold L. Hintz, Westvaco

Jeffery S. Hsieh, Georgia Institute of Technology 
PULP AND PAPER MUL OF THE FUTURE - AN INFORMATION EXCHANGE

September 8-10, 1993

ATTENDEES LIST

(continued)

Betty Ingraham, University of Maine

Erdogan Kiran, University of Maine

Andrew Klein, U.S. Department of Energy

Dave Kraske

Gopal A. Krishnagopalan, Auburn University

Eric D. Larson, Princeton University

Ryszard Lec, University of Maine

Frank W. Lorey, Garden State Paper Company

Tony Lyons, REPAP Technologies, Inc.

Andrej Macek, National Institute of Standards \& Technology

Gerald Maestas, Los Alamos National Laboratory

Earl W. Malcolm, Institute of Paper Science \& Technology

Dan W. Manson, Manson and Associates

Stanley Marshall, University of Maine

Steven Martin, Advanced Refractory Technologies, Inc.

Michael E. McLlwain, Idaho National Engineering Laboratory

William T. McKean, University of Washington

Chris Meyers, Aqua Dynamics Group Corp.

Paul Niskanen, Lanxide Corporation

John R. Obst, USDA FS Forest Products Laboratory

David Orloff, Institute of Paper Science \& Technology

Jeff Paschke, Aqua Dynamics Group Corporation

Suhas V. Patankar, Innovative Research, Inc.

Hemant P. Pendse, University of Maine

John G. Penniman, Paper Chemistry Laboratory, Inc.

Delmar R. Raymond, Weyerhaeuser

Wayne B. Robbins, Institute of Paper Science \& Technology

C. James Sample, APMA

Dale W. Schaefer, Sandia National Laboratories

Thomas W. Schmidt, Oak Ridge National Laboratory

Jack Sibold, Coors/Golden Technology

Philip S. Sklad, Oak Ridge National Laboratory

Stanely Sobczynski, U.S. Department of Energy

'Daniel J. Sordelet, Ames Laboratory

Charles A. Sorrell, U.S. Department of Energy

Edward V. Thompson, University of Maine

James R. Thrift III, Georgia Power Company

Thomas H. Ulrich, Idaho National Engineering Laboratory

Pertti Visuri, Ahlstrom USA

Jake Ward, University of Maine

Ira A. Weinstock, USDA FS Forest Products Laboratory

Ainslie T. Young, Los Alamos National Laboratory 



\section{INTERNAL DISTRIBUTION}

1-2. Central Research Library

3. Document Reference Section

4-5. Laboratory Records Department

6. Laboratory Records, ORNL RC

7. ORNL Patent Section

8-10. M\&C Records Office

11. D. J. Alexander

12. K. B. Alexander

13. L. F. Allard

14. M. Ally

15. R. Anderson

16-66. P. Angelini

67. R. L. Beatty

68. P. F. Becher

69. T. M. Besmann

70. P. J. Blau

71. E. E. Bloom

72. R. A. Bradley

73. C. R. Brinkman

74. T. D. Burchell

75. W. H. Butler

76. C. H. Byers

77. N. C. Cole

78. R. H. Cooper, Jr.

79. J. V. Coyner

80. D. F. Craig

81. J. H. Cushman

82. S. A. David

83. R. B. Dinwiddie, Jr.

84. J. R. DiStefano

85. D. S. Easton

86. D. E. Fain

87. M. K. Ferber

88. A. T. Fisher

89. E. P. George

90. B. G. Gieseke

91. G. M. Goodwin

92. W. L. Griffith

93. H. W. Hayden, Jr.

94. L. L. Horton

95. J. A. Horton, Jr.
96. C. R. Hubbard

97. J. O. Hylton

98. M. A. Janney

99. D. R. Johnson

100. R. R. Judkins

101. M. A. Karnitz

102. J. R. Keiser

103. E. A. Kenik

104. R. J. Lauf

105. E. Lee

106. C. T. Liu

107. R A Lowden

108. G. M. Ludtka

109. L. K Mansur

110. P. J. Maziasz

111. D. W. McDonald

112. D. J. McGuire

113. R. A McKee

114. K. L More

115. R. Murphy

116. R. K. Nanstad

117. T. A. Nolan

118. M. Olszewski

119. O. Omatete

120. A. E. Pasto

121. S. Pawel

122. K. P. Plucknett

123. J. B. Roberto

124. F. Ruppel

125. M. L. Santella

126. A. C. Schaffhauser

127. J. H. Schneibel

128. T. W. Schmidt

129. V. K. Sikka

130. P. S. Sklad

131. S. Spooner

132. R. W. Swindeman

133. B. Taljat

134. T. N. Tiegs

135. S. Viswanathan

136. J. M. Vitek 
137. X. L. Wang

138. K E. Wilkes

139. I. G. Wright

140. L. M. Wright

141. T. Zacharia
142. H. W. Foglesong (Consultant)

143. E. L. Menger (Consultant)

144. J. G. Simon (Consultant)

145. K. E. Spear (Consultant)

\section{EXTERNAL DISTRIBUTION}

146. ABB Combustion Engineering, 1000 Prospect Hill Road, Windsor, CT 06095

Robert Jacobs, CEP 8151-2324

147. ABB Combustion Engineering, 911 West Main Street, Chattanooga, TN 37402

Domenic A. Canonico

148. ABB Combustion Engineering, 200 Great Pond Drive, Windsor, CT 06095-0568

Mark LeBel

149. AFPA, 1250 Connecticut Avenue, NW \#210, Washington, DC 20036

Matthew Van Hook

150. APMA, 2608 E. Meredith Drive, Vienna, VA, 22181

C. James Sample

151. Advanced Refractory Technologies, 7800 Foxhound Road, McLean, VA 22102

Michael Kelley

152-153. Advanced Refractory Technologies, Incorporated, 699 Hertel Avenue, Buffalo, NY 14207

Steven Martin

Keith Blakely

154. Ahlstrom Recovery, Inc, 30 Mansell Court, Roswell, GA 30076

Rolf Ryham

155. Ahlstrom USA, 8925 Rehco Road, San Diego, CA 92121

Pertti Visuri 
156. Alabama Pine.Pulp Company, Inc, P.O. Box 100, Perdue Hill, AL 36470

Sunil Chandnani

157. AlliedSignal Inc, Ceramic Components Division, P. O. Box 2960, MS:T21,Torrance, CA 90509-2960

Maxine L. Savitz

158. American Forest and Paper Association, 1111 19th St., N.W., Washington, D.C. 20036

David Cooper

159. Ames Laboratory, 107 Metals Development, Ames, Iowa 50011

Daniel J. Sordelet

160. Andritz Sprout Bauer, Sherman Street, Muncy, PA 17756

Ronald L. Musselman

161-162. Aqua Dynamics Group Corporation, P.O. Box 849, 330 Maple Street, Adamsville, TN 38310

Chris Meyers

Jeff Paschke

163. Argonne National Laboratory, 340 L'Enfant Promenade SW, Washington, DC 20024

Frank Stodolsky

164-166. Argonne National Laboratory, 9700 South Cass Avenue, Argonne, Il 60439

James E. Battles

William A. Ellingson

Thomas E. Fritz

167. ASME, 1835 L Street, NW, Suite 906, Washington, DC 20036

Gregory B. Barthold

168. Auburn University, Department of Chemical Engineering, 230 Ross Hall, Auburn University, AL 36849

Gopal A. Krishnagopalan 
169. BE\&K, 2000 International Park, Birmingham, AL 35243

Barry Seidel

170. BEAK Consultants, Ltd, 3285 Cavendish, Suite 610, Montreal, Quebec H4B 2L9

Paul Stuart

171-172. Baboock \& Wilcox, 1562 Beeson Street, Alliance, OH 44601-2196

Todd Johnson

Robert Mcllroy

173. Babcock \& Wilcox, 2302 Parklake Drive, NE, Suite 300, Atlanta, GA 30345

Robert Larsen

174-176. Babcock \& Wilcox, 20 S. Van Buren Avenue, P.O. Box 351, Barberton, OH 44203-0351

Joan Barna

John Clement

J. William Smith

177. Bailey Controls Company, 29801 Euclid Avenue, MS 2L8, Wickliffe, OH 44092

William Thompson

178. Bareiss Associates, 10301 Bellwood Avenue, New Port Richey, FL 34654

Robert Bareiss

179-180. Battelle, 505 King Avenue, Columbus, OH 43201

Shalendra Porwal

Jeffrey Colwell

181-183. Battelle Pacific Northwest Laboratories, Department of Materials Science,

P.O. Box 999, Richland, WA 99352

Douglas C. Elliott, K2-40

W. D. Samuels, K2-44

Joan Young, K6-54

184. Beloit Corporation, Rockton R\&D Center, 1165 Prairie Hill Road, Rockton, IIL 61072

L. Busker 
185. BETZ, 8811 N. Harborview Drive, Gig Harbor, WA 98335

James Neff

186-187. BIRL - Industrial Research Lab, Northwestern University, 1801 Maple Avenue, Evanston, Il 60201-3135

John Fildes

Richard Johnson

188. Black Clawson Company, 605 Clark Street, P.O. Box 16, Middleton, OH 45042

Peter Seifert

189. Boise Cascade Corporation, 1300 Kaster Road, St. Helens, OR 97051

Darryl Dodson-Edgars

190. Boise Cascade Corporation, Technical Association of the Pulp \& Paper Industry, 4435 North Channel Avenue, Portland, OR 97217

Carol Wiseman

191-193. Bowater, Inc, 5020 Highway 11, South, Calhoun, TN 37309

John E. Griffey

LeRoy Hershey

Mark Rofier

194. Center for Technology Transfer, 59 Exeter Street, Portland, Maine 04043

Robert L. Dalton

195-197. Champion International, West Nyack Road, West Nyack, NY 10994

Dave Bennett

Samuel Suh

Erdan Yuzak

198. Coors/Golden Technology, 4545 McIntyre Street, Golden, CO 80403

Jack Sibold

199. Corporation on Resource Recovery and the Environment, 601 Pennsylvania Avenue, NW Suite 900, Washington, DC 20004

Patricia J. Dollar 
200-202. EG\&G Idaho, Inc, P.O. Box 1625, Idaho Falls, ID 83415-2218

Elmer Fleischman

Michael E. McLlwain

Robert M. Neilson, Jr.

203. ESPRI, SUNY, College of Environmental Science and Forestry, 1 Forestry Drive, Syracuse, NY 13210

Raymond C. Francis

204. Empire State Paper Research Institute, 310 Walters, SUNY-ESF, Syracuse, NY 13210

Ram Ramarao

205. Energetics, Incorporated, 7164 Gateway Drive, Columbia, MD 21046

Paul Bayer

206. William A. Foster, 3000 Scarborough Lane, Midland, MI 48640

207. Foxboro, 6659-L Peachtree Industrial, Norcross, GA 30092

Torsten Wesslen

208. Garden State Paper Company, 669 River Drive Center 2, Elmwood Park, New Jersey 07407

Frank W. Lorey

209. Georgia Institute of Technology, School of Materials Engineering, 778 Atlantic

Drive, Atlanta, GA 30332-0245

Jeffery S. Hsieh

210. Georgia-Pacific, 8480 Sentinae Chase Drive, Roswell, GA 30076

Gary Gettmann

211-214. Georgia-Pacific Corp., 133 Peachtree Street, NE, Atlanta, GA 30303

A. D. Armstrong

Veli Lapinoja

Karl T. Morency

Raymond Taylor 
215. Georgia Power Company, 21st Floor, 333 Piedmont Avenue, Atlanta, GA 30308 James R. Thrift III

216. Giese \& Associates, P.O. Box 4154, Kent, WA 98032

Bob Giese

217. P. H. Glatfelter Company, 228 S. Main Street, Spring Grove, PA 17362

Jon Myers

218. Samuel Goldberg, 9208 Burning Tree Road, Bethesda, MD 20817

219. Goraveiken, 8008 Corporate Center Drive, Charlotte, NC 28226

Joe Barsin

220. T. M. Grace Company, Incorporated, 2517 S. Harmon Street, Appleton, WI 54915

Thomas Grace

221-224. Herty Foundation Development, P.O. Box 7798, Savannah, GA 31418

James Anderson

Karl M. Counts

Michael Kocurek

Martin Schroeter

225-229. Idaho National Engineering Laboratory, EG\&G Idaho, P.O. Box 1625, Idaho Falls, ID 83415-2218

Elmer Fleischman

John E Flinn

D. Kunerth

E. S. Peterson

Thomas H. Ulrich

230-231. Idaho National Engineering Laboratory, P.O. Box 1625, M/S 2208, Idaho Falls, ID 83409

Charles A. Allen

Jim Mills

232. Innovative Research, Inc, 2800 University Avenue SE, Minneapolis, MN 55414

Suhas V. Patankar 
233-247. Institute of Paper Science \& Technology, Inc, 500 10th Street, N.W., Atlanta, GA 30318
Cyrus Aidun
Sujuit Banerjee
Donald Dimmel
Richard Ellis
H. Jeff Empie
Jack Firkins
Maclin S. Hall
Robert H. Horton
Earl W. Malcolm
Thomas McDonough
Dave Orloff
Authur J. Ragauskas
Wayne Robbins
Alan W. Rudie
Lucinda B. Sonnenberg

248. International Paper, Long Meadow Road, Tuxedo, NY 10987

Alexander Bonsu

249. International Paper, P.O. Box 160707, Mobile, AL 36616

Russell Andrews

250. International Paper, P.O. Box 2787, Mobile, AL 36652-2787

Subhash Pati

251-252. James River Corporation, 349 N.W. 7th Avenue, Camas, WA 98607-2090

Dennis Forbes

Ray Witter, Manager, Pulping Recovery \& Utilities Engr.

253. James River Corporation, 4th and Adams, Camas, WA 98607

W. W. Vantzelfden

254-255. James River Corporation, Corporate R \& D, P.O. Box 899, Neenah WI 54957-0899

Gary A. Baum

William Steed 
256-257. James River Corporation, P.O. Box 2218, Richmond, VA 23217

\section{Ronald Estridge}

Thomas Single

258. J. H. Jansen Company, P.O. Box 630, Woodinville, WA 98072

Allan Walsh

259. KAMYR, 101 Ridge Street, Glens Falls, NY 12801

Phill Mitchell

260-261. Kimberly Clark Corporation, 2100 West Winchester Road, Neenah, WI 54957

Steven Edwards

Ted Farrington

262. David Kraske, P.O. Box 673, Canton, ME 04221

263-264. Kvaerner Pulping, 8008 Corporate Center Drive, Charlotte, NC 28226

Joe Barsin

Bo Oscarsson

265. Lanxide Corporation, Government Development Programs, 1300 Marrows Rd.,

P.O. Box 6077, Newark, DE 19714-6077

Paul Niskanen

266. Lawrence Berkeley Laboratory, 1 Cyclotron Road, Mail Stop 90-2024, Berkeley, CA 94720

Arlon J. Hunt

267. Arthur D. Little, Aeorn Park, Cambridge, MA 02159

W. E. Clarke

268-269. Los Alamos National Laboratory, P.O. Box 1663, Los Alamos, NM 87545

Gerald Maestas, MS F643

Ainslie T. Young, G756 
270. MTT Energy Laboratory, E40-453, MTT, 77 Massachusetts Avenue, Cambridge, MA 02139

Elisabeth M. Drake

271-272 MTCI, 5570 Sterrett Place, Suite 20, Columbia, MD 21044

Amal Mansour

Momtaz Mansour

273. MTCI - ThermoChem, 13080 Park Street, Santa Fe Springs, CA 90670

K. Durai-Swamy

274. MacMillan Bloedel, P. O. Box 336,Pine Hill, AL 36769

Wallace Baxter

275. Madison Paper Industries, P.O. Box 129, Madison, Maine 04950

Jack Chinn

276. Manson and Associates, 1230 Brookhaven Park Place, Atlanta, GA 30319

Dan W. Manson .

277. R. C. Massey, 400 Mablsen Street, Alexandria, VA 22314

278. Mead Central Research Laboratories, Materials Engineering, Eighth and Hickory Streets, P.O. Box 1700, Chillicothe, OH 45601

Thomas P. Roberts

279-280. Mead Corporation, Courthouse Plaza N.E., Dayton, OH 45463

Karl Ayers

Jack Goldfrank

281. Miami University, 244 Gaskill Hall, Oxford, OH 45056

William Scott

282. Monadnock Process Engineering, 37 Champney Street, Groton, MA 01450

Harold Davis 
283. NCASI, 260 Madison Avenue, New York, NY 10016

John Pinkerton

284-285. National Institute of Standards and Technology (NIST), Gaithersburg, MD 20899

Andrej Macek, Physics Building, Room B 312 .

James R. Whetstone, B312, Bldg. 221

286-290. National Renewable Energy Laboratory, 1617 Cole Boulevard, Golden, CO 80401-3393

Joseph Bozell

Esteban Chornet

Helena L. Chum

Eric Hass

Ralph Overend

291-292. North Carolina State University, Box 8005, Raleigh, NC 27695-8005

Med Byrd

Hou-min Chang

293. O'Neal Engineering, Inc, P.O. Box 10269, Greenville, SC 29603

James Rushton

294. Oregon State University, Dept. of Chemical Engineering, Gleesm 103, Corvallis, OR 97331

W. J. Frederick

295. Orion CEM, Inc, 2939 Flowers Road S. \#130, Atlanta, GA 30341

H. Rumph

296. Osmotek, Inc, 30636 Peterson Road, Corvallis, OR 97333

Robert Salter

297. PFSL, Box 3890, Portland, OR 97331

Richard Haynes

298. Paper Chemistry Laboratory, Inc, P.O. Box 930, Carmel, NY 10512

John G. Penniman 
299. PAPRICAN, 3800 Wesbrook Mall, Vancouver B.C., Canada, V6S2L9

Douglas Singbeil

300-301. Parson \& Whittemore, Inc., P. O. Box 65, Perdue Hill, AL 36470

Sunil Chandnani

Adam Melton

302. Potlatch Corp, Cloquet, MN 55720

John M. Smuk

303. Princeton University, Center for Energy \& Environmental Studies, Princeton, NJ 08544-5263

Eric D. Larson

304. Procter \& Gamble Cellulose, P.O. Box 8407, Memphis, TN 38108-0407

David Streit

305. Pulp \& Paper Research \& Education Center, 242 Ross Hall, Auburn University, Alabama 36849

Harry T. Cullinan

306. REPAP Technologies, Inc, 2650 Eisenhower Avenue, Valley Forge, PA 19482-0766

Tony Lyons

307. Resource Recovery, Inc, 220 Washburn Road, P.O. Box 1016, Caribou, Maine 04736

Al Cyr, Sr.

308. RUST Engineering, P.O. Box 101, Birmingham, AL 35201

Robert Kinstrey

309. Sandia National Laboratories, Department 8701, Livermore, CA 94551

Duane Lindner 
310-311. Sandia National Laboratories, Division 8361, P.O. Box 969, 7011 East Avenue, Livermore, CA 94551-0969

Taz Bramlette

Jay Keller

312. Sandia National Laboratories, 1515 Eubank, S.E., Albuquerque, NM 87185-5800

Dale W. Schaefer, Division 1810

313. Sandvik Steel Company, P. O. Box 1220, Scranton, PA 18501-1220

James M. Noble

314-315. Scott Paper Company, Scott Plaza II, Philadelphia, PA 19113

Keith Johnson

Bernard Yaros

316. Scott Paper Company, 3120 Riverside Avenue, Marinette, WI 54143

Frank H. Pichette

317. Simpson, Tech. Dept. Manager, 400 Mill Street, Oregon, OR 97068

Y. P. Fang

318-319. Stone \& Webster, Advanced Systems Devt. Service, 245 Summer Street, Boston, MA 02210

John' Racine

Richard Steiger

320-322. Stone Container Corporation, 8170 S Madison, Burr Ridge, IL 60521

Algis Mockaitis

Max Moskal

Chuck Timko

323. Stone Container Corporation, 1979 Lakeside Parkway, Tucker, GA 30084

William Wilkinson

324. TAPPI, P.O. Box 105113, Technology Park/Atlanta, Atlanta, GA 30348

Don Gilmore 
325. TAPPI, 15 Technology Parkway S., Norcross, GA 30092

G. Julian Reid

326. TEKES Technology Development Center, Box 69, SF-00101, Helsinki, Finland Christine Hatstrom-Nasi

327. Textron Defense Systems, Coal Technology, 2385 Revere Beach Parkway, Everett, MA 02149

Richard C. Diehl

328. ThermoChem, Incorporated, 5570 Sterrett Place, Suite 21, Columbia, MD 21044

Henry Said

329. ThermoChem, Incorporated, 5570 Sterrett Place, Suite 210, Columbia, MD 21044

David A. Scearce

330-331. U.S. Dept. of Energy - Boston, 1 Congress Street, Boston, MA 02114

Robert Allen

Roger C. Bavoux

332-361. U.S. Department of Energy/Headquarters, 1000 Independence Avenue, SW, Washington, DC 20585

Stan Blazewecz, EE-221, 5F-035/FORS

David Boron, Office of Industrial Technologies

Cliff Carwile, EE-222, 5F-035/FORS

Bruce Cranford, Office of Industrial Waste Reduction

Sidney Diamond, EE-34, 5G-064/FORS

Sara Dillich, EE-232, 5F-059/FORS

Christine Ervin, EE-1, 6C-016/FORS

Simon Friedrich, Office of Industrial Technologies

Thomas Foust, EE-222, 5F-035/FORS

Pat Hoffman, EE-232, 5F-043/FORS

Ehr Ping HuangFu, EE, Office of Industrial Technologies

Theo Johnson, EE-221, 5F-035/FORS

Douglas E. Kaempf, EE-234, 5F-043/FORS

Susanne Leonard, EE-222, 5F-035/FORS

Matthew J. McMonigle, EE-234, 5F-058/FORS

William A. Obenchain, EE-231, 5G-067/FORS

William P. Parks, Jr., EE-221, 5F-035/FORS

Marsha L. Quinn, EE-223, 6H-034/FORS

Scott L. Richlen, EE-221, 5F-035/FORS 
Neil Rossmeissl, Office of Industrial Technologies

Peter H. Salmon-Cox, EE-23, 5F-059/FORS

Kurt Sisson, EE-222, 5F-035/FORS

Merrill Smith, EE-70, 6A-025/FORS

Stanley F. Sobczynski, EE-231, 5F-059/FORS

Charles A. Sorrell, EE-232, 5F-059/FORS

Denise F. Swink, EE-20, 6B-052/FORS

Tina VanSickle, EE-233, 5F-059/FORS

Gideon Varga, EE-221, 5F-035/FORS

Daniel E. Wiley, EE-233, 5F-059/FORS

Valri Wright, EE-222, 5F-035/FORS

362-366. U.S. Department of Energy, 19901 Germantown Road, Germantown, MD 20585

James P. Carr, FE-72, 3035/270

Robert J. Gottschall, ER-131, J-322/GTN

Helen Kerch, ER-131, J-322/GTN

Richard Peavy, DP-4.1, GP-180/FORS

F. W. Wiffen, ER-533, G-258/GTN

367. U.S. Department of Energy/Oak Ridge, Building 4500N, Mail Stop 6269, P.O. Box 2008, Oak Ridge, TN 37831-6269

E. E. Hoffman

368. U.S. EPAORD/OEETD, 401 M Street SW, Washington, DC 20460

Gregory Ondich

369-374. USDA FS Forest Products Laboratory, 1 Gifford Pinchot Drive, Madison, WI 53705

Said M. Abubakr

Peter J. Ince

John Koning

John R. Obst

Theodore Wegner

Ira A. Weinstock

375-376. Union Camp Corporation, P.O. Box 3301, Princeton, NJ 08543-3301

Richard Barker

Dave Crowe

377. University of Florida, Chemical Engineering, Gainesville, Florida 32611

Oscar Crisalle 
378. University of Florida, Room 429, Gainesville, Florida 32611

Art Fricke

379. University of Maine, Chemistry Department, 5706 Aubert Hall, Orono, Maine 04469-5706

Barbara Cole

380-381. University of Maine, Department of Industrial Cooperation, 117 Boardman Hall, Orono, Maine 04469-5711

Mike Boyle

Jake Ward

382. University of Maine, Electrical Engineering, Orono, ME 04469

Ryszard Lec

383-390. University of Maine, 5737 Jenness Hall, Orono, ME 04469-5737

Douglas Bousfield

Toshibaru Enomae

Joseph M. Genco

Marquita Hill

Betty Ingraham

Erdogan Kiran

Hemant P. Pendse

Edward V. Thompson

391. University of Maine, Pulp \& Paper Foundation, 5737 Jenness Hall, Orono, ME 04469-5737

Stanley Marshall

392. University of Minnesota, 2004 Falwell Avenue, St. Paul, MN 55108

Henry Wells

393. University of Washington, College of Forestry, Seattle, WA 98115

Rick Gustafson

394. University of Washington, Department of Paper Science and Engineering, Chem. Engineering Dept., BF-10 Seattle, WA 98195

William T. McKean 
395. S. D. Warren Company, Research Laboratory, Westbrook, ME 04092 David Rolfe

396. Western Michigan University, McCracken Hall, Kalamazoo, MI 49008

Raja G. Aravamuthan

397. Westvaco, 299 Park Avenue, New York, NY 10171

Harold L. Hintz

398-399. Westvaco Corp, 11101 John Hopkins Road, Laurel, MD 20707-0000

Lad Falat

W.B.A. Sharp

400. Weyerhaeuser Company, Energy R\&D, Tacoma, WA 98401

Densmore Hunter

401-402. Weyerhaeuser Company, 32901 Weyerhaeuser Way South, Federal Way, WA 98003

Margaret Gorog, Materials R\&D, WTC-1C39

Peter Gorog, WTC-2H22

403-405. Weyerhaeuser Company, Tacoma, WA 98477

Peter Ariessohn, WTC-2H 22

Tom Friberg, WTC-2D19

Robert J. McTee, WTC 1C39

406. Weyerhaeuser Company, Weyerhaeuser Technology Center, WTC 1B24, Tacoma, WA 98477-0001

Delmar R. Raymond

407. Weyerhaeuser Company, P.O. Box 1830, Columbus, MI 39703-1830

Joe May

408. David G. Wirth, 14390 W. 30th Avenue, Golden, CO 80401

409-411. Department of Energy, Office of Scientific and Technical Information, Office of Information Services, P.O. Box 62, Oak Ridge, TN 37831

For distribution by microfiche as shown in DOE/OSTI-4500, Distribution Category UC-310 [Industrial Programs (General)] 
.

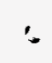

